\title{
Toward a Political Ecology in Early South India: Preliminary Considerations of the Sociopolitics of Land and Animal Use in the Southern Deccan, Neolithic through Early Historic Periods
}

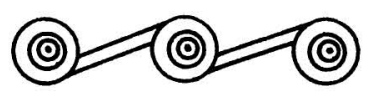

\author{
ANDREW M. BAUER, PETER G. JOHANSEN, AND \\ RADHIKA L. BAUER
}

\section{ARCHAEOGRAPHY AND HUMAN ENVIRONMENT RELATIONSHIPS IN EARLY SOUTH INDIA}

The ARCHAEOLOGY OF SOUTHERN INDIA has long been dominated by research programs that have had as their concern the production of archaeological cultures seated within culture-historic narratives of the past (Johansen 2003; Morrison 1994). While this is not aberrant from global historical norms in the practice of archaeological systematics, it does obfuscate analyses of detailed sociohistorical processes by generalizing social, political, and economic behavior as proxies for a culture type. One of the most pervasive problems of cultural historical interpretations of the archaeological record is the tendency among researchers to focus on short, interstitial periods of change caused by punctuated and cataclysmic factors. As the prehistory of South India is marked by categories of material culture that are lengthy and perduring, the nature of this patterning has served to reinforce notions of long periods of cultural "homeostasis" punctuated by events of dramatic change. Explanations for these episodes of change were once almost exclusively characterized by diffusionary causation (e.g., Allchin and Allchin 1982; Leshnik 1974; Wheeler 1948). More recently, however, environmental stimuli have become a frequently deployed explanatory frame for "culture change" (e.g., Dhavalikar 1984; Korisettar and Rajaguru 2002; Shinde 1998). Yet in either case, the structure of the interpretive framework has created a relatively fixed set of relationships between the environment and past human societies in South Indian prehistory, generally manifested either as dependency or adaptation.

While the insertion of the environment was a much-needed contribution to earlier diffusionary models of South Indian culture history, human-environmental

Andrew M. Bauer and Peter G. Johansen are Ph.D. candidates in the Department of Anthropology at the University of Chicago, Chicago, Illinois. Radhika L. Bauer is a 2006 Ph.D. in the Department of Anthropology at the University of Pennsylvania, Philadelphia, Pennsylvania. 
relationships are often portrayed with little attention to the complexities of sociocultural practices. Instead, a "culture" is thought to display adaptive "reactions" to environmental change or stasis that in turn structure society. Adaptation to environmental change or stasis is then viewed as having a remarkably profound effect (or sets of effects) on that "culture," oversimplifying issues of agency and causation in largely deterministic terms. At issue here is a lack of adequate treatment for the sociopolitical complexity of human-environment relationshipsspecifically, for a politics of ecology.

Previous work has been of considerable value for building the foundations of archaeological knowledge of early South India. ${ }^{1}$ It is clear that throughout the time period between 3000 B.C. and A.D. 500, new modes of labor mobilization and axes of social difference become visible-notably reflected in South India by the construction of megalith monuments (e.g., dolmens, menhirs, and stone circles), often containing subsurface burial cists with single or multiple interments and a variety of fine ware ceramics, iron implements (e.g., weapons, tools, and horse trappings), beads, and copper and bronze objects (Figs. 1, 2) (Brubaker 2001; Leshnik 1974; Moorti 1994). Here we examine the relationships between emerging sociopolitical differences and both stable and dynamic aspects of socioculturally mediated land use throughout the South Indian Neolithic (3000-1200 B.C.), Iron Age (1200-500 B.C.), and Early Historic (500 B.C.-A.D. 500) periods in the southern Deccan region of South India.

In an attempt to contextualize such practices in wider sociopolitical realms, we focus on the empirical components of three aspects of the archaeological record-animal use, agricultural regimes, and monument production and maintenance - through a lens of political ecology, or what Rocheleau (1999:22) identifies as a focus on "the social relations of power" and the production of "ecologies and landscapes." Accepting that land use is socially mediated and influenced by cultural logics and knowledge systems, we suggest that sociopolitical distinctions emergent from the second millennium B.C. to the first millennium A.D. in South India could be viewed in relation to the historical production of a landscape that differentially included wild and domesticated animals, cultivars, water reservoirs, irrigation agriculture, ritual places, and monumental architecture. In this sense, we aim to shed light on the complex relationships between sociopolitical practices and the ecological-material conditions they produce and in which they operate.

\section{POLITICAL ECOLOGY: POLITICIZING "NATURE" AND SOCIALIZING HUMAN-ENVIRONMENT INTERACTIONS}

The mechanistic treatment of human-environment interaction in Indian historiography is by no means unique when considered within scholarship more generally, as much archaeological and paleoecological research has been unable to transcend such schematized frameworks. Indeed, recent studies have related social "collapses" in both Mesopotamia and South America to abrupt climatic shifts (e.g., Cullen et al. 2000; Kolata et al. 2000; Weiss et al. 1993). In brief, many discussions have centered on establishing synchronization between environmental changes and social transformations. 


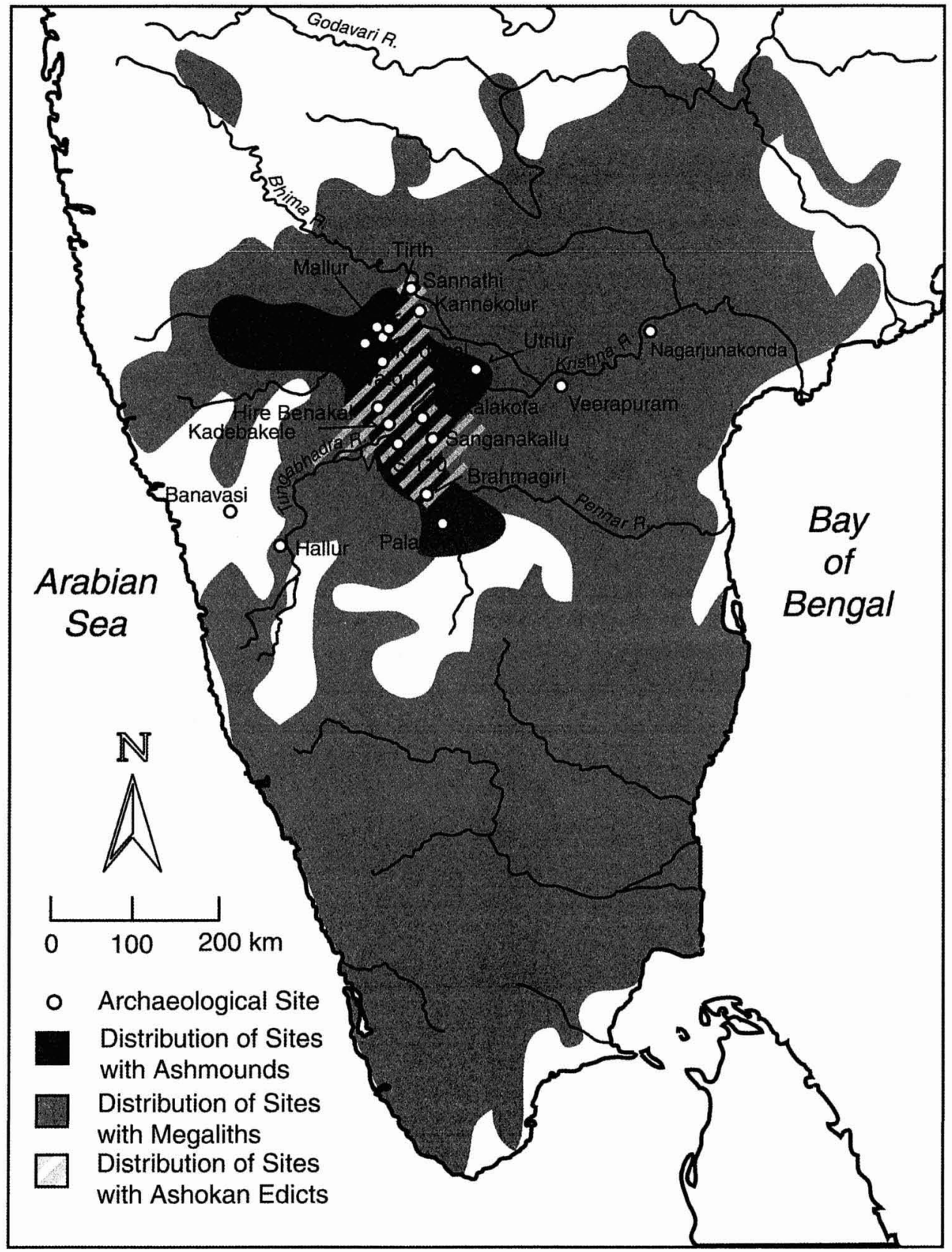

Fig. 1. Location map showing the principal sites of the southern Deccan discussed in the text and the distribution of ashmounds, megaliths, and Ashokan edicts in the region. Note that Asokan edicts in the southern Deccan occur at the sites of Erragudi, Rajula-Mandagiri, Maski, Gavimath, Palkigundu, Nittur, Udegolam, Brahmagiri, Siddapura, Jatinga-Ramesvara, and Sannathi (Sugandhi 2003) but are here represented by area shading to reduce cartographic complications. 


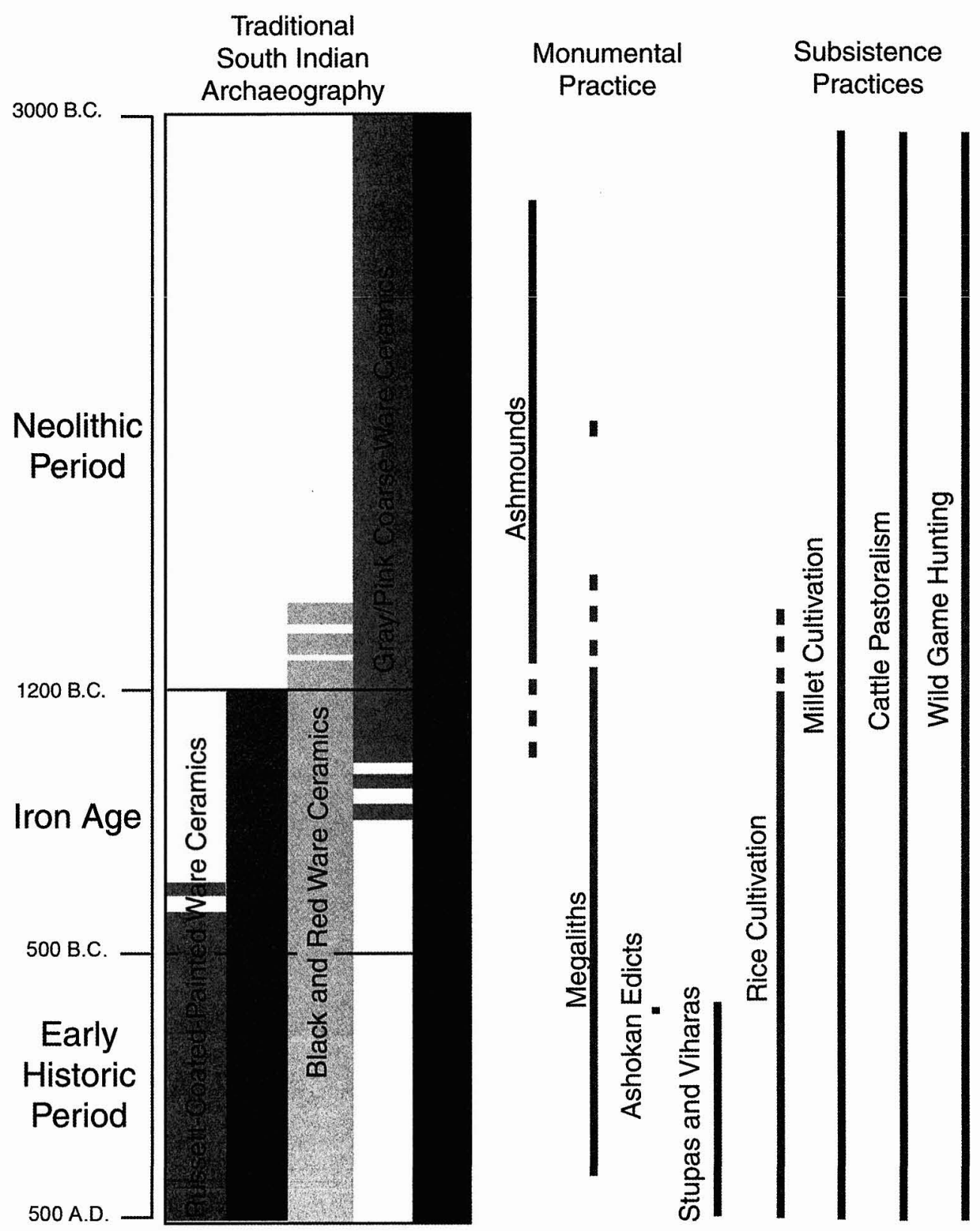

Fig. 2. South Indian chronology, 3000 B.C.-A.D. 400: traditional archaeography and its relationship to sociohistoric processes discussed in the text.

Earlier anthropological attempts at integrating humans with environmental processes introduced a well-founded concern for human-environment interactions in the social sciences and arguably expanded recognitions that humans are partly producers of environmental phenomena (e.g., Butzer 1982; Rappaport 1968). Indeed, the relationships between social and environmental change remain 
critical lines of inquiry (e.g., Lepofsky et al. 2005). However, several intellectual movements have begun to challenge previous frameworks as overly deterministic and reductive to addressing the complexities of human-environment interaction. Foremost among them has been the development of the "New Ecology," which has challenged the validity of underlying assumptions of homeostasis and adaptation to equilibrium-like conditions inherent in most models of human-ecosystem approaches. $^{2}$ The New Ecology dismisses the equilibrium paradigm and argues that biophysical environmental systems should be viewed as dynamic and historical. In other words, normative conditions are not "natural" (Botkin 1990; but also see Worster 1994), and relationships between sociocultural practices and the environment must be conceptualized as intricate, context-dependent, and under constant (re)negotiation (Erickson 1999; Scoones 1999). Building on the move to historicism, historical ecologists have recognized that environmental phenomena are as much the product of specific historical human actions as they are of "natural" processes (e.g., Crumley 1994; Morrison in press a). Thus, the degree to which "cultural" and "natural" processes can be legitimately isolated has been called into question. Moreover, contemporary ethnography has also produced an implicit critique of many previous approaches to human-environment interaction by challenging the rigid distinctions between nature and culture that are imposed in most models. For example, Descola (1994) has demonstrated that some societies conceive of the "natural" world as an extension of the social, in which case human interactions with other environmental constituents (e.g., plants, animals, landforms, etc.) are partly shaped by their respective status as part of society. In other words, ethnographic accounts show the need for emphasis on cultural logics and social perceptions of the environment in analyzing the historical relationships between people and their material world.

It has become increasingly recognized that "nature" is comprised of a historical materiality in specific sociocultural contexts. Hence, attempts to avoid the determinisms of earlier approaches seek to examine the relationships between humans and their environments without necessarily subordinating either "nature" or "culture" to the other. As Ingold (2000:43-45) has rightly suggested, to argue that the "natural" is an extension of the social still assumes a determinative ontological distinction between nature and culture - the latter being mapped onto the former. While in methodological practice these dichotomies are difficult to avoid (and perhaps are even desirable to keep), one strategy to elude the reduction of nature to culture or vice versa conceives of human interactions as part and parcel of the environments they inhabit (Ingold 2000). In other words, a "peopled" ecology is becoming a potentially productive avenue for research (Erickson 1999; Morrison in press a; van der Leeuw 1998). In this case, emphasis is placed on the processes through which both the social and the natural are historically coconstituted. This project has a particular salience to the emerging body of scholarship on political ecology.

Although lacking a singular orientation, advocates for a political ecology have argued that human-environmental relationships are socially mediated; thus, analyses of such interaction must consider material constraints and possibilities within the social and political fields in which they are constituted (e.g., Greenberg and Park 1994). Initially, the term "political ecology" was used in an effort to interject the concerns of political economy into determinative ecological models of culture 
that previously sought to explain behavior solely in terms of adaptation to an environment. This scholarship called attention to social relations of production and larger socioeconomic structures influencing local land use and ecological processes (e.g., Blaikie and Brookfield 1987; Wolf 1972). More recently, post-structuralist scholarship has begun to shift focus toward issues of local practice, decentralized power, discourse, and knowledge (Biersack 1999). Proponents for the investigation of human-environment relations through discourse have argued that this move will refocus political ecology on "politics" itself; that is, on how "control and access of resources or property rights are defined, negotiated, and contested within ... political arenas" (Peet and Watts 1996:9). Moreover, part of the program of political ecology has become the investigation of the processes by which the sociomaterial world is categorized, codified, and produced as knowledge in the service of political interests - either intentionally or unintentionally (e.g., Fairhead and Leach 1996; see also Escobar 1999 and Latour 2004). Such recent trends in political ecology have shed important light on the degree to which situated social perceptions, conceptions, and representations of human-environment interactions can have profound consequences in producing both social and ecological conditions (e.g., Fairhead and Leach 1996; Neumann 2004). However, Vayda and Walter's (1999:168) contention that political ecology is increasingly becoming "politics without ecology" is a well-warranted critique of some analyses. Overemphasis on political discourse risks neglecting the ecological-material conditions and processes that are constituted as the objects of those politics.

As archaeologists, we maintain an emphasis on the materiality of socioecological phenomena, and here we adopt Rocheleau's concerns for the relationships between "social relations of power" and the production of "ecologies and landscapes" (1999:22). Following from this, we define the "political" of political ecology as the negotiation of access to social and symbolic resources upon which power is based (after Smith 1999). In this case, it is possible to make a distinction between "sociopolitical" - as the negotiation of social relationships and differential access to social resources - and formal "politics" (see also Paulson et al. 2005). We believe our data, to date, are primarily suggestive of the former and thus find political ecology's recent focus on decentralized power to be useful.

Following Rocheleau (1999), we also argue that political ecology must consider the historical materiality that people both engage and comprise, and therefore we link political ecology to the social production of landscapes (see also Fairhead and Leach 1996; Morrison in press a). Landscapes include the cultural meanings that were attributed to places in the past as they were historically produced through changes in how people's activities and perceptions relate to their material environments (cf., Bradley 1998, 2000; Ingold 2000; Smith 2003). Hence, the production of landscape can be profoundly political, as social claims are materialized through monuments, and places characterized by inclusively and exclusivity, access and restriction, or moral and immoral activity are differentially made and remade (e.g., Kus and Raharijaona 2000; Smith and David 1995). Indeed, Harvey (1990) has gone so far as to suggest that social relations in general are profoundly spatial phenomena. While Harvey's analysis of twentieth-century capitalism is perhaps not applicable to the pre/protohistory of South India, questions concerning the reconstitution of places as land use changed are certainly relevant. Because patterns of land use are socially mediated and shaped by histori- 
cally situated cultural logics, a diachronic examination of land/animal use may evince how land use practices shape and are shaped by material conditions, logics, knowledge systems, and social relationships that are both constituted and constitutive of their specific historical contexts. With this in mind, we turn to archaeological evidence from South Indian Neolithic through Early Historic Period sites in a preliminary effort to suggest how the concerns of political ecology may be integrated with South India's unique archaeological datasets for animal use, agricultural regimes, and monument production and maintenance. Before making these suggestions, however, it is necessary to first broadly explore the empirical foundations of the archaeological record in the South Deccan region as a whole.

\section{EMPIRICAL BACKGROUND TO THE ARCHAEOLOGICAL RECORD}

\section{OF SOUTH INDIA}

The temporal spread that encompasses the period between 3000 B.C. and A.D. 500 has traditionally been divided into three periods in South India- the Neolithic, Iron Age/Megalithic, and early historic-each generally congruent with a "culture" or "people" in much of the archaeological literature. The beginning, end, and duration of each period varies according to researcher but conforms largely to the time line presented below. In all cases, the presence or absence of one or more material culture traits serves as a hallmark of each period. Despite the problematic nature of cultural historical paradigms, much valuable information has been generated through decades of careful archaeological research.

The South Indian Neolithic (3000-1200 B.C.) was initially constructed on the pioneering work of Robert Bruce Foote (1916) following the discovery of a geographically diverse distribution of ground and pecked stone tool types across a large swath of what is today southern India. The Neolithic period, however, has become synonymous with Mortimer Wheeler's (1948) Stone Axe Culture, identified by the presence of ground stone axes and a coarse gray/pink handmade ceramic industry. Despite the focus on temporally insensitive artifact types, over a century of research on the Neolithic period has established an outline of human life during these times. ${ }^{3}$ Cattle pastoralism and millet farming were clearly crucial elements of food production regimes throughout the period, but other domestic and wild food resources were also regularly utilized. This is evidenced by an ever-increasing sample of faunal and macrobotanical remains (cf., Fuller 2003; Korisettar et al. 2001b; Paddayya 2001) from the North Dharwar and South Deccan regions. Village settlements across the region were positioned largely away from major drainages in areas that were conducive to rain-fed agriculture and abundant pasturage. ${ }^{4}$ At some sites, large cattle pen enclosures were present. Additionally, many sites in the region have ashmound features constructed of burned and vitrified cattle dung. Korisettar et al. (2001b) have argued for a functional distinction between ashmound and non-ashmound sites in which the former are viewed as seasonal or semisedentary settlements.

The South Indian Iron Age (1200-500 B.C.) - or as it is somewhat erroneously referred to, the megalithic period ${ }^{5}$ - has been the subject of scholarly research for nearly two centuries. The majority of archaeological work on this period has focused on the megalithic monuments and sepulchres that were ubiquitously con- 
structed throughout South India during the Iron Age (see Fig. 1). The period and its archaeological "culture" are empirically correlated with megalithic memorial architecture, the presence of iron, and a black and red ware ceramic industry.

Interpretations of Iron Age social organization have been largely constructed on evidence from monument and mortuary evidence. Megaliths are a class of features constructed of locally available stone and often earth. They range in form from dolmens, menhirs, and stone circles to cobble- and boulder-filled crack features on granite outcrops. Often (but by no means always), these monuments contain subsurface burial cists with single or multiple interments. Varieties of grave goods are associated with excavated megaliths, consisting primarily of fineware ceramics, iron implements (e.g., weapons, tools, and horse trappings), beads, and copper and bronze objects. Moorti (1994), Leshnik (1974), and others have used disparities of this kind to argue for a stratified Iron Age society (see also Brubaker 2001).

Very little systemic archaeological work has been conducted on Iron Age settlements (but see Krishna Sastry 2003; Sinopoli and Morrison 2003) until recently. Settlement during the Iron Age appears to have been spatially diverse. Village settlements of variable size, and some with specialized economic production, occur in a wider variety of settings than during the Neolithic period (cf., Johansen 2004; Morrison in press a; Sinopoli et al. in press). Indeed, several of the larger settlements were located near major river drainages. Research suggests that agricultural practices had become increasingly diversified and perhaps intensified during the Iron Age, as evidenced by a wider distribution of domesticates and the construction of reservoirs and other water and soil retention features (see below).

Lastly, the Early Historic Period (500 B.C.-A.D. 500) in South India is distinguished in depositional and material terms from the Iron Age largely by the presence of a modification to some black and red ware ceramic vessels involving the application of a light russet-colored wash and painted design (Russet-CoatedPainted Ware-Wheeler's “Andhra Ware”). Conceptually, however, the period was designated as one during which writing first appeared in South India. This is traditionally associated with the minor rock edicts of Asoka (reigned 268-231 B.C.), despite the existence of several well-documented cases of Brahmi script "graffiti" on ceramics from deposits likely predating the Mauryan Empire's incursions into South India.

Settlement during this period expanded considerably throughout South India, with much evidence for pan-Indian and long-distance trade, including areas as far away as the Mediterranean (see Begley 1996; Begley and De Puma 1991; Cimino 1994). The size and dispersal of major settlements increased considerably during the Early Historic Period, and inscriptional and textual data on specific dynastic polities and actors are prevalent. This is also the period when Buddhist and Jain religious institutions became established in South India, evidenced by the remains of monastic and devotional architecture and inscriptions detailing a wide social range of patronage for these institutions (Morrison 1995a; Ray 1986, 2003; Sinopoli 2001).

Given the historical outline provided above (see also Fig. 2), we now turn to a more detailed discussion of the archaeological evidence for how monument production, animal use, and agricultural regimes can be considered in relation to the 
development of sociopolitical differences during the South Indian Neolithic through the Early Historic Period.

\section{MONUMENT PRODUCTION AND MAINTENANCE}

Throughout the longue durée of pre- and protohistoric South India, the character and location of monumental architecture and spatial production has changed in step with broader regional sociopolitical developments. Here we consider monuments as nonprosaic, public architecture that is symbolically charged and produced through material practices embedded within the politics of established and unfolding social relations (Lefebvre 1991).

The production of monumental space in South India began toward the middle of the third millennium в.C. during the Neolithic period, with the construction and maintenance of ashmounds by the inhabitants of the South Deccan region. These large mounded features were constructed through incremental heaping and burning of cattle dung and other culturally modified sediments (Fig. 3). Ashmounds appear to have been located both within and on the margins of sedentary and semisedentary agro-pastoral settlements ${ }^{6}$ (Allchin 1963; Johansen 2004; Paddayya 1991, 1998, 2001). While it is likely that ashmound production began as quotidian practices associated with cattle keeping and stock enclosure maintenance, at some point during Neolithic times these prosaic activities became moored to a schedule of sociosymbolic ritual practices through which many ashmounds achieved monumental size and form. The repetitive ritual practice through which these monuments were produced involved the use of an evidently valued, sacrilized substance collected from an animal with well-documented economic and symbolic importance to Neolithic society.

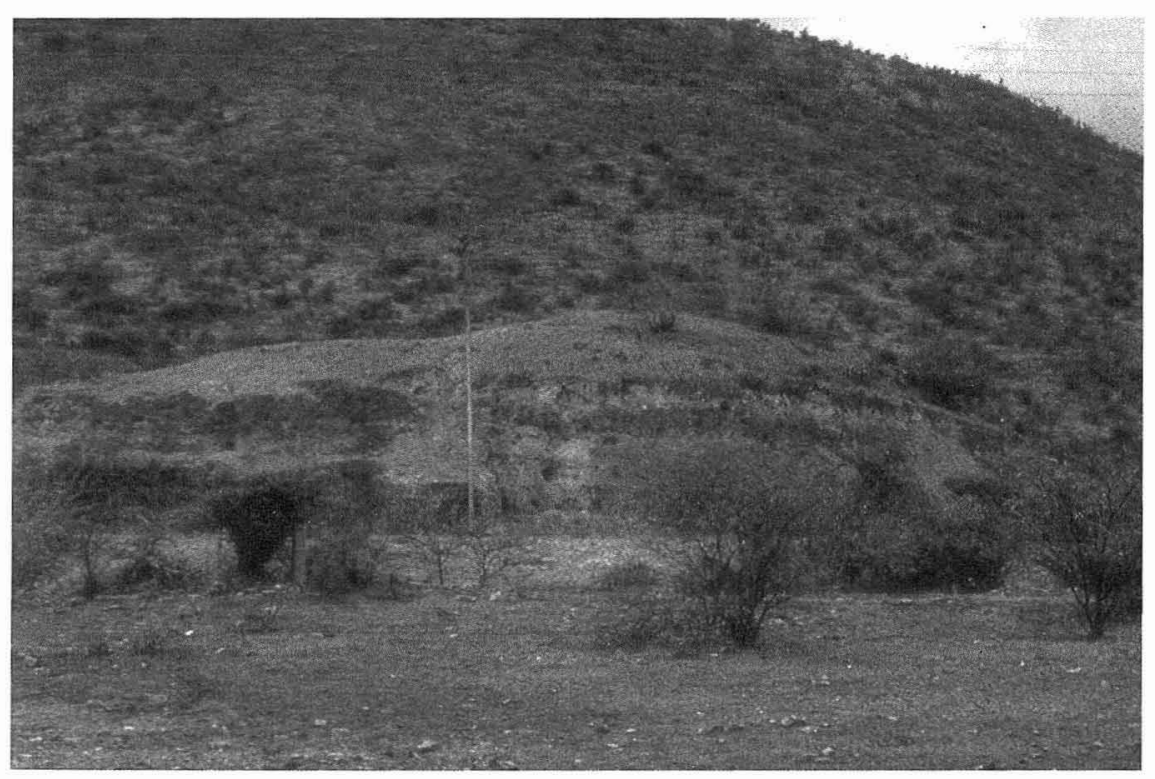

Fig. 3. Neolithic ashmound at the site of Kudatini (photo courtesy of Carla Sinopoli). 
The practices associated with ashmound production were clearly informed by a unique set of cultural logics and knowledge systems through which the economic and symbolic importance of cattle to unfolding Neolithic social relationships was expressed through ritual transformations involved in the production of these monuments within a cultural landscape (see Boivin 2004a; Johansen 2004). The construction of ashmounds during the second and third millennia B.C. was slow and incremental and appears to have been associated with both small- and largescale community and corporate practices that do not suggest social relations characterized by hierarchical differences or rigid institutionalized social inequalities. Exposed sections of ashmound features demonstrate an episodic tempo to their construction, which may denote seasonal, intraseasonal, and generational scales of production. Their formation also entailed a differential rhythm of production, distinguishable by frequent small-scale deposition and burning of dung and dirt from less frequent high-temperature burning of much larger quantities of dung and the periodic capping of the dung with sterile sediments. What can be discerned from the archaeological record of ashmounds that have been carefully exposed is that their construction and maintenance was structured, repetitive, cyclical, and public (Johansen 2004). In the single case where horizontal excavations were conducted in the area surrounding an ashmound, the feature was found to be centrally located within a small village community without notable differences between habitation structures or burial treatment (i.e., Budihal-S: see Paddayya 1993, 1998, 2001). Indeed, there is very little evidence from Neolithic period burials or habitational deposits from across South India for hierarchical social differences, as differences in mortuary treatment during this period are largely restricted to the distinction between infants and adults. ${ }^{7}$

By the late second millennium B.C., the processes involved with ashmound construction were on the wane. This corresponded in turn with changes in regional settlement dynamics, agricultural land-use, and mortuary traditions. During the Iron Age (1200-500 B.c.), monuments continued to be erected as part of the regional landscape, but they were constructed of stone and earth (i.e., megaliths) instead of cattle dung. The distribution of megalithic monuments is far more widespread than that of ashmounds (see Fig. 1), appearing in virtually every region of South India and encompassing a broad range of large stone architecture such as menhirs, dolmens, stone circles, and a wider variety of landscape alterations such as cobble alignments and cobble-filled outcrop cracks (Krishnaswami 1949; Leshnik 1974; Lycett and Morrison 1998; Morrison 2004). Megaliths are found in a variety of contexts, ranging from relatively isolated sites with one or two monuments to massive and elaborately designed secluded hilltop complexes. Excavations of many megaliths (especially dolmens and stone circles) have evidenced mortuary status inequalities, suggesting that new axes of social differences were emerging during the period. For example, burials containing the excavated remains of multiple individuals can be contrasted with individual burials, both occasionally within large stone circles, "sometimes tens of metres in diameter, enclosing cairns covering elaborate chambers (with capstones frequently weighing a ton or more)" (Brubaker 2001 : 278; see also Gururaja Rao 1972; Thaper 1957). The scale and complexity both of the construction of these monuments and the nature of grave goods associated with them vary both within and between sites (Brubaker 2001; Leshnik 1974; Moorti 1994). 
In short, Iron Age mortuary traditions attest to changes both in the range and degree of potential status designations and strategies involved in the organization of labor from Neolithic times. Stone and earth became the preferred construction material for monumental architecture, perhaps as dung found more quotidianthough not necessarily less symbolically charged-uses in manuring regimes consistent with broader and more intensified agricultural practices. ${ }^{8}$ Many megalithic complexes and features associated with settlement sites appear carefully planned and executed with an accretional pace of construction (Brubaker 2001). Yet the physics involved with hewing, moving, and assembling large stone monuments speaks to a potentially different mode of power relations involved in the organization of labor for these tasks; a shift in sociopolitical relations is also inferred from mortuary traditions across South India.

In addition to evincing potential social inequalities, preliminary associations between megalithic monuments and water reservoirs suggest that water took on special cultural significance during the Iron Age, and that perhaps there was differential access to it. Large concentrations of elaborately constructed megaliths appear to have been deliberately placed adjacent to water basins in isolated hilltop locations. The site of Hire Benakal in northern Karnataka represents a striking example of such an association (Fig. 4). There, hundreds of megaliths are found near a broad, shallow water basin that likely began as a "natural" rock pool and was subsequently expanded by quarrying activities for the construction of monuments. ${ }^{9}$ In addition to Hire Benakal, Gordon and Allchin reported 80 megaliths

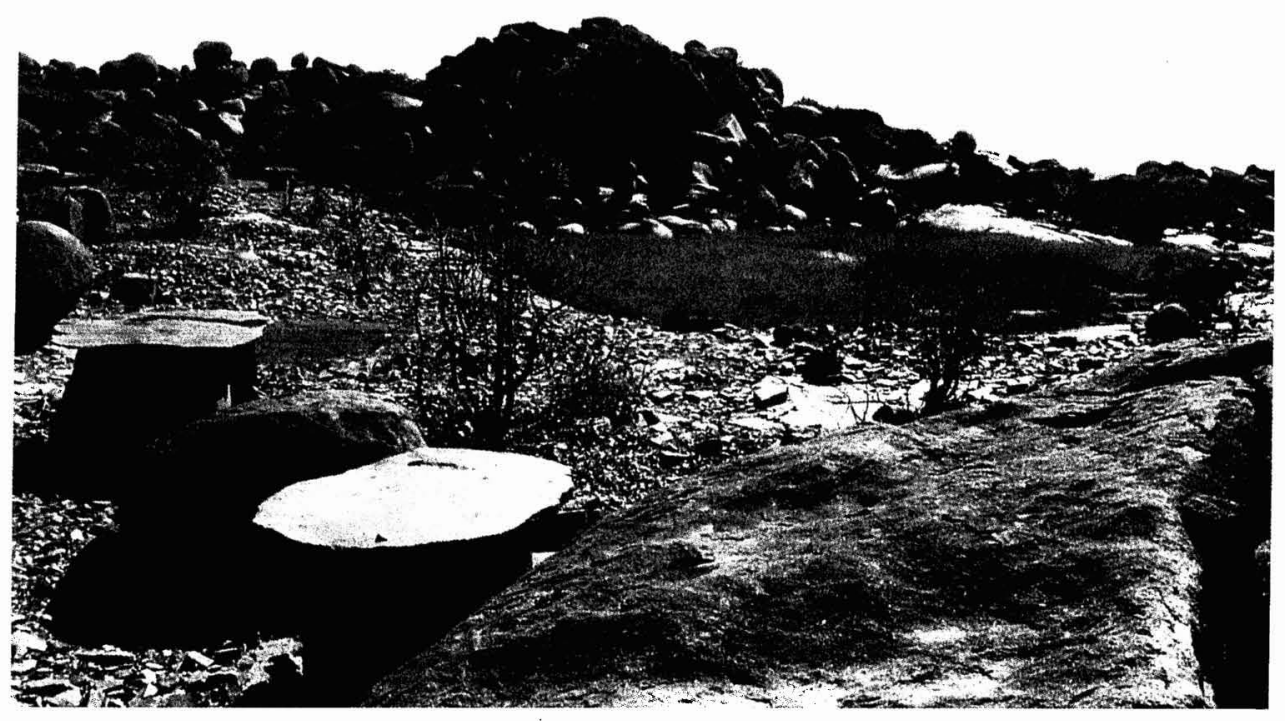

Fig. 4. Site of Hire Benakal, showing dolmen megaliths in association with an early reservoir feature. 
at a site near Bilebhavi, where they identified two "tanks," one "lined with stone slabs" (1955:99). Moreover, they recorded a similar construction on a hilltop megalith site near Koppal. While these associations are suggestive of a ritual dimension to early water management in the region, few of these observations are the product of systematic research and await corroboration from detailed methodical survey. Nevertheless, preliminary associations between megalithic monuments and culturally significant water pools may have served as a particular claim of access to "ritual" water, and they furthermore could have reinforced or reconfigured perceptions of developing sociopolitical differences (see also Bauer and Morrison in press). Indeed, impressionistic observations at several such sites suggest that the most pronounced monuments are generally those most proximate to such water features.

Toward the end of the first millennium B.c., there are further additions to the repertoire of monumental architecture in South India, most of which are associated with political and ideological developments in northern India. In the central Tungabhadra corridor and surrounding region, the Mauryan emperor Asoka (reigned 268-231 в.C.) commissioned edicts inscribed into natural rock faces or onto architectural elements. While not truly architectural, the Rock Edicts of Asoka are certainly monumental in their nonprosaic detail. Both location and language of inscription may suggest that many of these edicts were not intended to be viewed and/or read by large segments of the regional populations (cf., Sugandhi 2003). Other important monuments during the early historic period include Buddhist viharas (monastic complexes) and stupas (memorial/devotional monuments) constructed in the South Deccan, such as those at Sannathi, Banavasi, and Nagarjunakonda. These developments came in the wake of much broader and intensified social, political, and economic relations with northern India, especially the states of the Ganga Valley, and certainly affected the configuration, perception, and imagination of both monumental and prosaic spaces and the social and political fields of action that were both product and producer of this social, political, and material web of relations.

\section{EARLY ANIMAL USE IN THE SOUTHERN DECCAN}

The relationships between human and animal populations are complex and multidimensional; the sociocultural significance of animal populations and animal products may include a host of activities, ranging from consumption to reverence. Thus, measures of animal identity and contextual associations as indicated from archaeological faunal analyses provide patterns through which social dimensions of animal use can be evaluated, such as the relative abundance of wild versus domesticated taxa in certain contexts, the dietary importance of nonmammalian species, and the specific composition of domestic herds. These data inform on practices of stock herding, as well as the exploitation of wild species through hunting, trapping, and fishing. As suggested by a host of diverse anthropological studies, such activities have different social implications, perhaps in terms of differential consumption, time/labor investment, technologies, and division of labor (e.g., Dahl and Hjort 1976; Jones and Konner 1976; Lee 1968; Speth 1983; Spooner 1973). Considering such implications, we review faunal data from ar- 


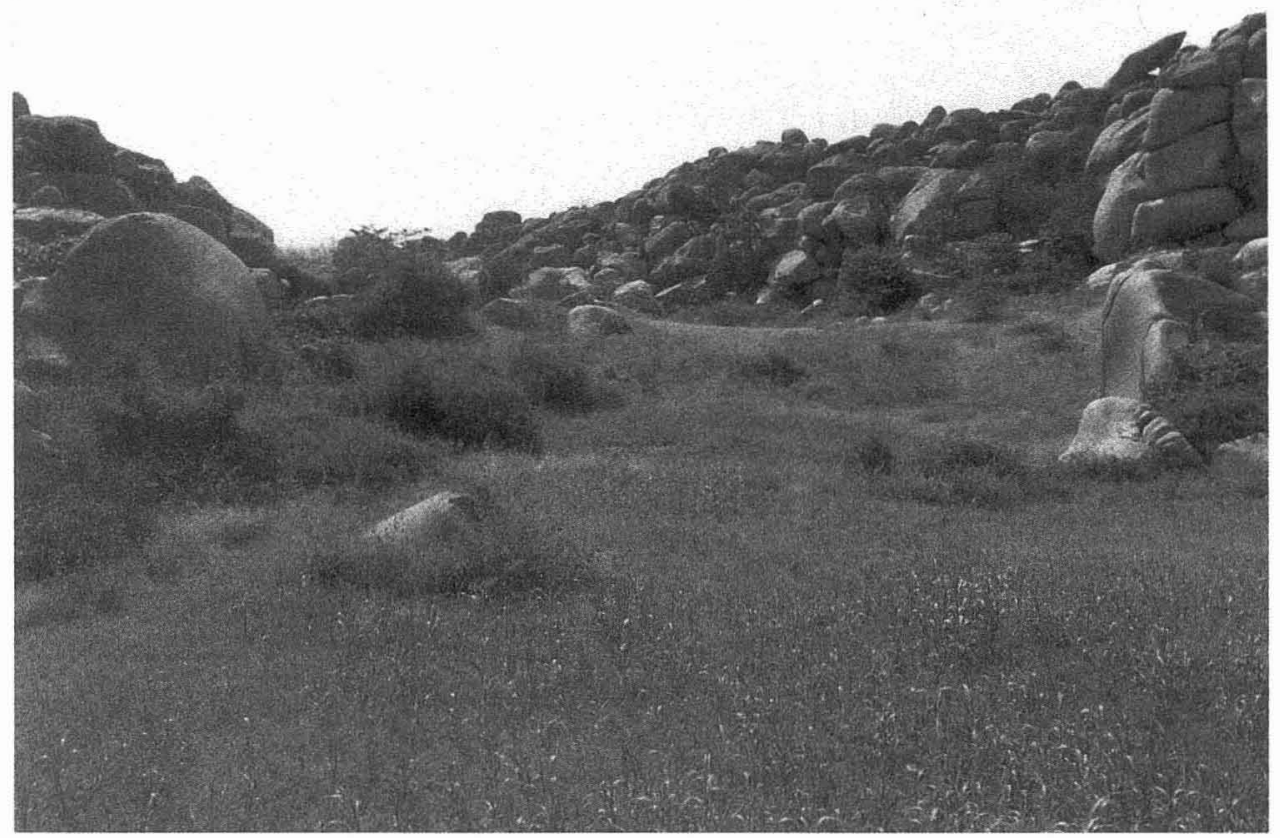

Fig. 8. Reservoir feature at Kadebakele, with millet growing in the foreground.

megalithic monuments, suggesting potential ritual dimensions of early water management (see above). Perhaps the most striking example of such an association is at Hire Benakal, where large dolmens are situated on the quarried bank of a water catchment basin. Although these early basins lack provisions for water distribution necessary for large-scale agriculture, some features occur within "natural" drainage ways in association with check dams and at the base of hills where water can be pooled and retained for crop production. It is difficult to characterize the entire range of variability in form and "function" of these water management constructions without more systematic work; however, it appears evident that water and soil retention techniques began to be practiced in a variety of landscape settings, ranging from simple check dams to quarried catchment basins (see also Allchin 1954). Moreover, the fact that they generally coincide with increases in crop diversity suggests that water management became increasingly important to agricultural production in the first millennium B.C. However, such techniques may have developed earlier. Indeed, Devaraj et al. (1995:66) report that "interlaced, hydraulically laminated" deposits "overlap and disappear against" an earthen construction near the base of a granite outcrop at Watgal, a settlement site of the fourth to first millennium B.C. ${ }^{14}$

More detailed investigations of consumption differences within Iron Age and Early Historic site contexts-which might potentially demonstrate social differences of access and dietary choices-remain to be carried out; however, it is possible to be suggestive of how changing agricultural regimes were potentially instrumental in the production of social differences during the periods considered 
Fuller and Korisettar (2004) have convincingly demonstrated that both anthropogenic influences as well as possible variations in monsoon strength were operative in producing the vegetational character of the peninsula in the mid-second millennium в.с. (for corresponding evidence of a decrease in monsoon strength, see Phadtare 2000). Thus, current evidence suggests that agricultural production intensified in the southern Deccan throughout the second millennium B.c. under a weakening monsoon (for a detailed discussion, see Fuller and Korisettar 2004).

Early food producers in the southern Deccan relied on mixed agro-pastoral subsistence regimes (Korisettar et al. 2001a). The early crop package characteristic of the Neolithic period included two native millets (Brachiaria ramosa and Setaria verticillata) and pulses (Macrotyloma uniflorum and Vigna radiata), which were likely cultivated during the summer monsoon (Fuller 2003; Fuller et al. 2001). In fact, several scholars have argued that sites from this period often occur near large topographic features where crop production could take advantage of seasonal runoff from surrounding hill slopes (e.g., Johansen 2004; Sinopoli et al. in press). On indirect lines, Fuller et al. (2001) have even suggested that early reservoir irrigation might have begun in this period, because both wheat (Triticum sp.) and barley (Hordeum vulgare) - which presumably require winter rains conspicuously lacking in central and eastern Karnataka-were introduced from northern India around the beginning of the second millennium B.c. (see also Fuller 2003; Kajale 1984). Moreover, by the end of the second millennium there appears to be a significant increase in other cultigens, including pigeon pea (Cajanus cajan), hyacinth bean (Lablab purpureus), finger millet (Eleusine coracana), and rice (Oryza sp.) (Fuller 2003; Fuller et al. 2001; Kajale 1989). The increasing diversity in crop production through the second and first millennia B.c. also coincides with a marked increase in grass pollen in the Karwar coast core (Caratini et al. 1994). Thus, it has been argued that agricultural practices in peninsular India became particularly pronounced by the late second millennium B.c. (e.g., Meher-Homji 1993, 1996), even with a possible onset of drier conditions (cf., Caratini et al. 1994; Fuller and Korisettar 2004). It is also likely that manuring practices either began or were intensified by the late second and early first millennia B.C. This has been suggested by several scholars (e.g., Fuller et al. 2001) and is indirectly evidenced by the reduced production of ashmound monuments during this period (see above). However, more direct evidence for manuring practices awaits detailed micromorphological and chemical analyses of ancient agricultural sediments.

Pulses, millets, wheat, and barley continued to comprise part of the crop assemblage throughout the first millennium в.с.; however, rice increasingly became an important crop in the region (see Kajale 1984). In fact, Morrison (in press b) has suggested that clustering of Iron Age/Early Historic Period settlements near the Tungabhadra floodplain may reflect the growing importance of river water for agriculture, particularly for the hydraulic requirements of rice.

By at least the first millennium B.C., there is evidence to suggest the development of more sophisticated water management. Reservoirs-constructed bunds or quarried catchment basins for pooling rainfall and runoff-begin to occur in many different contexts throughout the region. For example, at Kadebakele a reservoir was constructed near the center of the settlement overlooking the Tungabhadra floodplain (Fig. 8). Reservoirs from this period are also associated with 


\section{Proportion of Types of Burning}

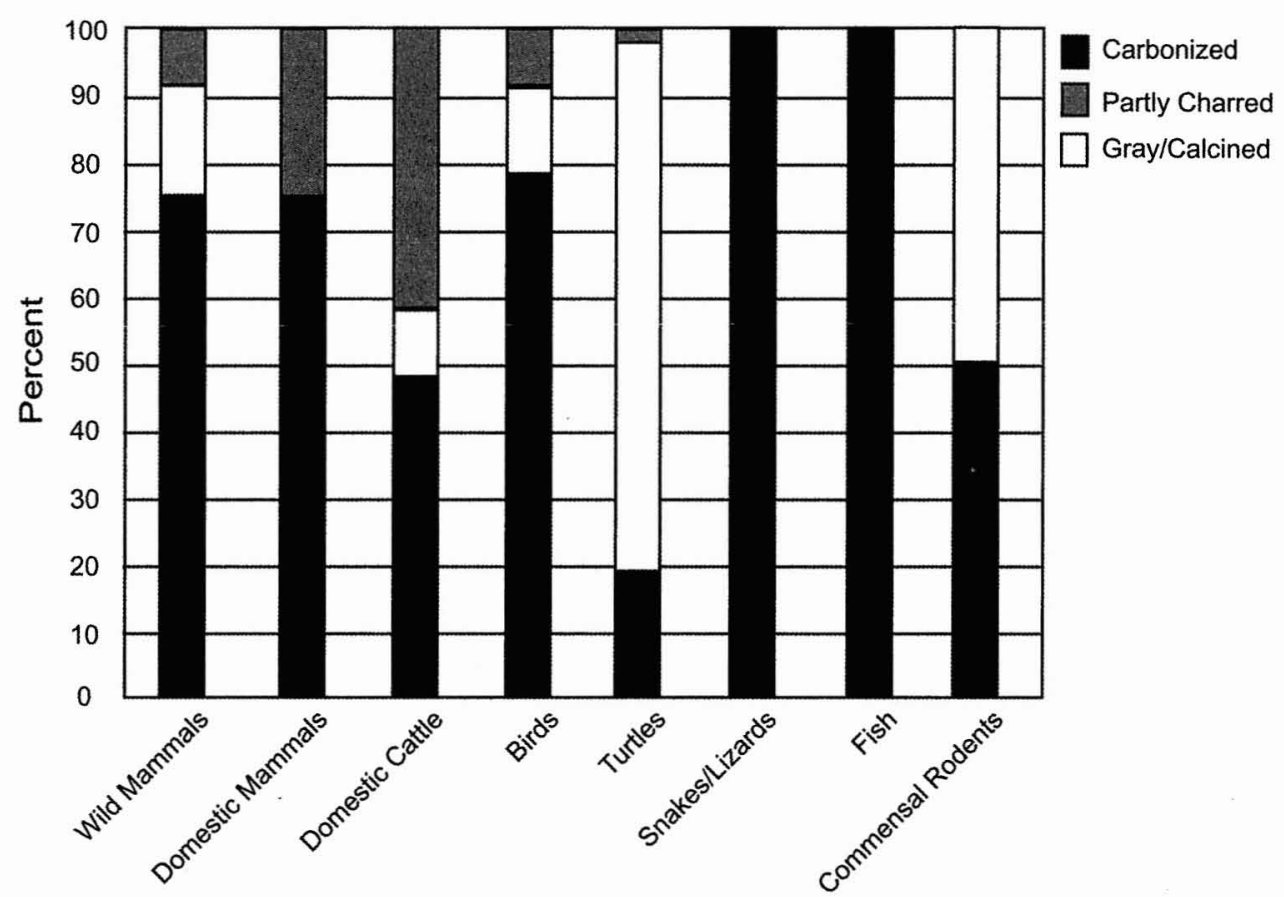

Fig. 7. Proportions of types of burning among various taxonomic categories. Note that cattle remains show the highest proportion of partial charring, which often indicates roasting.

indication that the intensity of hunting decreased during the Early Historic Period. This is particularly evident at the site of Veerapuram, where wild animal remains continue to be recovered from early historic contexts but in relatively smaller proportions (P. Thomas 1984 : vii; see also Monahan in press). ${ }^{13}$ These data attest to subtle shifts in animal use strategies rather than dramatic changes between periods.

\section{AGRICULTURAL REGIMES AND WATER MANAGEMENT}

The earliest agricultural production in central Karnataka can be firmly rooted in the South Indian Neolithic period, beginning in the early third millennium B.c. Both paleoecological analyses and paleosol characterizations have suggested that the region expressed a wetter and more humid climate than currently at the onset of this period (Caratini et al. 1994; Mujumdar and Rajguru 1966). However, using palynological and sediment records off the Karwar coast (western Karnataka), Caratini et al. (1994) have argued for a drying period due to a decrease in the strength of the monsoon around the mid-second millennium в.c. The proposition for a drastic decrease in the monsoon has been challenged by arguments that developing agricultural practices were responsible for changes in environmental proxy records, such as an increase in grass pollen due to agricultural intensification (Meher-Homji 1993, 1996; Subash Chandran 1997). However, 
and water buffalo comprising a significant proportion of the sample. Fusion and tooth-wear data demonstrate that domesticates were often kept until advanced age, suggesting that these animals were reared for secondary products rather than as a common source of meat. Metrical data indicate that the practice of castrating zebu bulls was undertaken to control the breeding population as well as to increase the labor potential of adult males. Indeed, osteological evidence indicates that some individuals were used for labor; five cattle elements bear signatures consistent with those produced by the repeated strain of traction labor. In addition, two elements bear evidence of tuberculotic infection (Mycobacterium bovis), which is known to infect cattle (and other mammals) under poor and crowded living conditions (i.e., corrals or pens) (Cosivi et al. 1998).

In addition, the distribution and deposition of cattle remains found at Kadebakele within a series of prepared burial pits capped by plaster surfaces and stones suggest that these animals were ritually important to Iron Age inhabitants (see R. Bauer 2006 and Morrison et al. n.d. for a more detailed discussion of these deposits). ${ }^{11}$ Despite the fact that many cattle across the site appear to have lived into old age, there are several indications that some younger (juvenile and prime-aged) individuals were consumed and interred within these pits, perhaps during feasting events. These deposits contained both a high degree of skeletal completeness and incidence of burned remains; patterns of burning across the site indicate that cattle portions tended to be prepared via roasting more than any other animal, and the highest proportion of these charred bones were recovered from the prepared pits (Fig. 7). Partially charred specimens can be readily interpreted as evidence of exposure to heat while the portion was partially fleshed and may serve as evidence of roasting meat, which could be further interpreted as a sign of conspicuous consumption (Jackson and Scott 2003 : 555).

In various prehistoric and historic cultural contexts, many scholars have associated the consumption of large mammals with communal feasting events, which tend to highlight social distinctions while promoting group cohesion (see Dietler and Hayden 2001; Jackson and Scott 1995; Potter and Ortman 2004). Burgeoning social differentiation documented during the Iron Age may have been tied into such communal events. Indeed, the importance of secondary products in the Iron Age subsistence economy would likely have imbued these domesticates with a great deal of social value, perhaps even denoting wealth to their owners. Provisioning the animals suitable for communal consumption may have bestowed social distinction on a group or individual and thus likely represented one dimension of negotiating sociopolitical positionality during the Iron Age. Moreover, because feasting activities involve the preparation and consumption of meat among large groups of people, these events may have emphasized dimensions of group identity, perhaps with regard to shared recognition of the value placed on cattle in general and the meaningfulness of the ritual structure that was created on the landscape. In short, the Kadebakele material indicates that both hunting and local stockbreeding practices were important components of social life during the Iron Age in the southern Deccan. It appears that sociopolitical distinctions were produced and negotiated based on differential participation in the production and consumption of herded and hunted animals.

Among published data for Early Historic Period sites in the southern Deccan, domestic cattle continue to dominate faunal assemblages. ${ }^{12}$ Moreover, there is some 


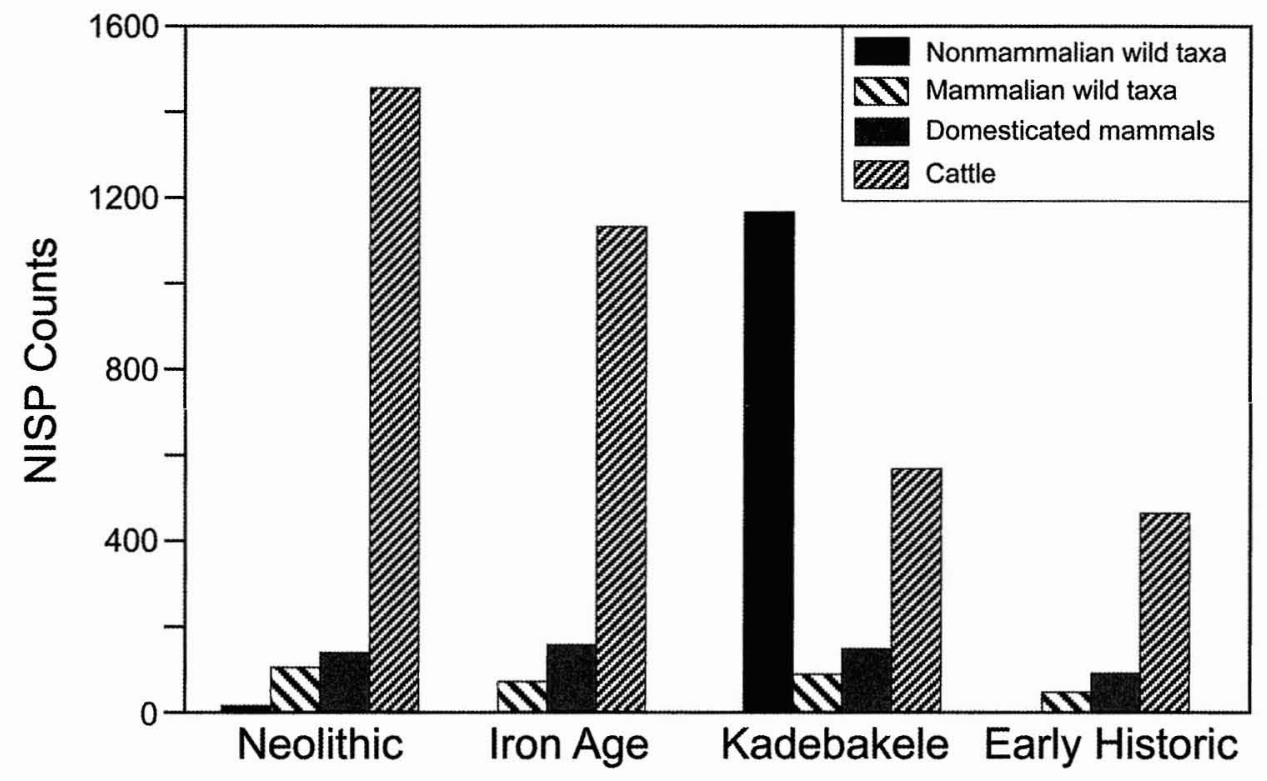

Fig. 6. Comparison of total number of identified specimens (NISP) at Kadebakele against compiled totals from other Southern Deccan Neolithic, Iron Age, and Early Historic Period sites. The sites included above are Tekkalakota (Nagaraja Rao 1965), Veerapuram (P. Thomas 1984), Kodekal (Clason 1975), VMS 110 (Monahan in press), Mallur (Clason 1975), Kannekolur (Clason 1975), Budikal (Clason 1975), Tirth (Clason 1975), Hallur (Alur 1971), Utnur (Allchin 1971), Pallavoy (Rami Reddy 1976), and Brahmagiri (Nath 1968). Nonmammalian wild taxa included here are birds, fish, turtles, crocodiles, snakes, and amphibians. Wild mammalian taxa include wild dog, wild ass, wild cat species, panther/leopard, Indian fox, chital, nilgai, sambar, muntjac, gaur, blackbuck, Indian gazelle, Indian hare, Indian porcupine, small primate (cf. macaque), mongoose, marten, flying fox, shrew, and rat (for all sites except Kadebakele, where rats are considered intrusive). Domestic mammals include donkey, horse, goat, sheep, domestic dog, domestic pig (for all sites except Kadebakele, where pigs are not decidedly identified as domesticated or wild). Cattle include both zebu and water buffalo specimens, given the difficulty in differentiating between the skeletal elements of these two species (e.g., Kijngam 1979; Korrisetter et al. 2001). Note that nonmammalian taxa are likely underrepresented at many sites due to variability in collecting (e.g., screened vs. unscreened) and reporting (e.g., presence/absence vs. NISP/MNI).

covery methods, commonly used in archaeological excavations in South India, which introduce biases against smaller taxa. Thus, in many respects it is difficult to evaluate comparisons between Kadebakele and other South Indian Iron Age sites and the differences between Iron Age and Neolithic animal use more generally (also see discussion section).

Nevertheless, it is clear that there was a diverse base of animals both hunted and herded during the Iron Age, and that production and consumption were largely oriented toward locally available wild resources. Procurement of these small wild taxa may serve as evidence for household consumption rather than communal sharing of large game, such as deer or antelope. Importantly, a diverse set of ethnographic cases often describes these small fauna as animals that can be hunted by virtually anyone; that is to say, social differences based on gender and age are not often associated with procurement of small wild animals as they are with the hunting of large game (Marks 1979; Rappaport 1968).

Domesticates were also part of the faunal assemblage at Kadebakele, with zebu 
Table i. List of Faunal Taxa Recovered at Kadebakele

\section{Fish}

Perch-type fish (Order Perciformes)

Ritha/catfish (Order Siluriformes)

Fish (species indeterminate)

Snakes/lizards/turtles/amphibians

Trinket snake (Elaphe helena)

Snake (species indeterminate)

Indian monitor lizard (Varanus salvator)

Skink (Mabuya or Lygosoma sp.)

Lizard (species indeterminate)

Indian tent turtle (Kachuga tentoria)

Deccan softshell turtle (Aspideretes leithii)

Turtle (species indeterminate)

Frog/toad (Order Anura)

\section{Birds}

Indian peafowl (Pavo cristatus)

Eagle (Aquila sp.)

Woodpecker (Dendrocopos sp.)

Lesser whistling duck (Dendrocygna javanica)

Jungle fowl (Gallus gallus)

Bird (species indeterminate)

\section{Mammals}

Water buffalo (Bubalus bubalis)

Zebu (Bos indicus)

Zebu or water buffalo (Bos or Bubalus)

Goat (Capra sp.)

Sheep/goat (Ovis/Capra)

Wild or domestic pig (Sus sp.)

Domestic horse (Equus caballus)

(probably) Wild dog (Canis sp.)

Gaur (Bos gaurus, based on size of specimen)

Nilgai (Bosephalus tragocamelus)

Sambar (Cervus unicolor)

Chital (Axis axis)

Blackbuck (Antilope cervicapra)

Leopard or panther (Panthera sp.)

Indian hare (Lepus nigricollis)

Indian porcupine (Hystrix indica)

Small primate (cf. Macaca)

Flying fox (Pteropus giganteus)

Mongoose (Herpestes edwarsii)

Wild cat (Felis sp.)

Nilgiri marten (Martes flavigula)

Shrew (Suncus sp.)

Rat/mouse (Rattus or Mus sp.)

the site (Table 1). These data contrast markedly with analyses of other South Deccan Iron Age sites, which show domesticates comprising 95 percent of the total identified specimens and cattle remains predominating overall (Fig. 6). However, such results are likely an artifact of unscreened hand-collection re- 
that cave visitors neither kept nor consumed domesticates at these sites during their visits. However, the general applicability of the Kurnool cave data to the rest of the Southern Neolithic remains to be seen.

In many ways, South Indian Iron Age economies resembled the agropastoralism attributed to Neolithic times, although differences do occur (Bauer et al. 2004; P. Thomas 1992, 1993). Studies have identified a similar range of domesticates, again with cattle predominating. Although it has been suggested that the importance of hunting was reduced following the Neolithic period ( $\mathrm{P}$. Thomas and Joglekar 1994:197), data suggest that animal economies were also diversifying throughout the peninsula during the Iron Age, with an increasing exploitation of wild animals such as birds (e.g., P. Thomas 1992, 1993).

At Kadebakele, a heavy dietary reliance on an array of nonmammalian wild animals was observed (R. Bauer 2006). Of these taxa, birds, turtles, and fish were more abundant in the assemblage than wild mammals, emphasizing the importance of avifauna and riverine taxa in the diet (Fig. 5). Indeed, cattle and water buffalo remains constitute a smaller fraction of the total identifiable specimens at

\section{Mammalian Taxa}

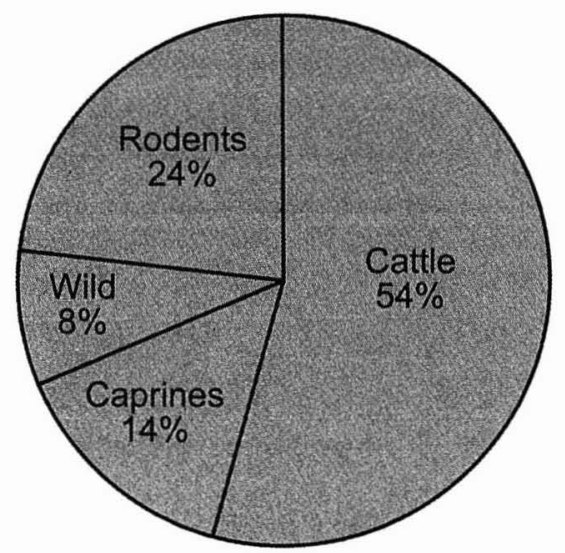

Nonmammalian Taxa

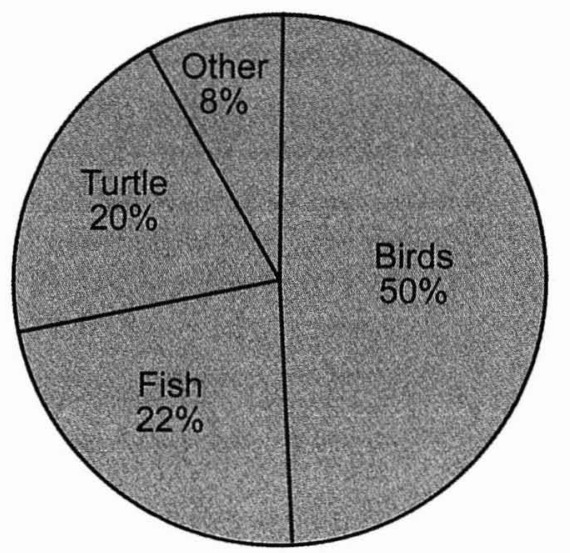

Fig. 5. Proportional composition of domestic and wild species recovered at Kadebakele. Cattle are 54 percent of the total number of identified specimens (NISP) for mammals and include zebu and water buffalo remains. Wild taxa constitute 8 percent of the total NISP for mammals and include panther/leopard, chital, nilgai, sambar, gaur, blackbuck, Indian hare, Indian porcupine, small primate (e.g. macaque), mongoose, marten, flying fox, and shrew. Rats and mice are considered separately as commensal rodents (24 percent of total mammalian NISP); these animals are likely intrusive to the majority of the archaeological deposits and should not be considered as evidence of wild mammal use at Kadebakele. Caprines are 14 percent of the total NISP for mammals and include specimens identified as goat or sheep/goat. One specimen identified as domestic horse is not included in the Mammalian Taxa chart. Pig remains are not included in any category above, as they were not definitively identified as either the wild or domestic variety. If pigs (NISP $=45)$ are included with the values for wild mammals, their relative proportion rises to 12 percent; however, if these animals are considered with caprines, the relative proportion of noncattle domesticates rises to 18 percent. Among wild species identified at Kadebakele, birds constitute 50 percent of the total NISP; these species include peacock, eagle, duck, jungle fowl, and woodpecker. Fish remains are 22 percent of the total NISP for nonmammals and include both catfish and perch-type fish. Turtle remains are 20 percent of the total NISP and include both Deccan softshell and Indian tent turtle varieties. Snakes, lizards, and frogs constitute 8 percent of the total NISP for nonmammalian taxa and include trinket snake, monitor lizard, skink, and frog/toad species. 
chaeological sites in the southern Deccan and present preliminary results from archaeological investigations at Kadebakele, conducted jointly by the University of Chicago/University of Michigan/Government of Karnataka EHLTC archaeological project. ${ }^{10}$

Kadebakele is a large Iron Age occupational site located in the Koppal District of inland northern Karnataka (see Fig. 1) (Morrison et al. n.d.; Sinopoli 2005a; Sinopoli et al. in press). The site is situated on one of a series of granite inselbergs that form a northwest-southeast trending range bordering the north side of the Tungabhadra River, where it approaches the geological divide of the Eastern Dharwar craton, Western Dharwar craton, and the Deccan Plateau basalts to the north (Naqvi and Rogers 1987). Positioned in the orographic rain shadow of the Western Ghats, the area is dominated by a semiarid climate that receives less than $500 \mathrm{~mm}$ of rain per year (India Meteorological Department 1981). However, as a result of being dependent on the strength of the monsoon, actual rainfall shows significant intra- and interannual variability. Most of the region's precipitation falls between June and October during the southwest monsoon. Characteristic vegetation primarily includes narrow-leafed, thorny trees and scrubs of the Albizia amara-Acacia series; however, human modifications have considerably altered the contemporary flora (Morrison 1995b; Singh 1988).

In general, the subsistence economy of the Neolithic period (3000-1200 в.c.) in this region has been described as agro-pastoral, with domestic cattle having both economic and symbolic significance (Allchin 1963; Allchin and Allchin 1982; Fuller 2001; Fuller et al. 2001; Murty 1992:335; Paddayya 1991, 1993; Paddayya et al. 1995). This explication is buttressed by the following observations: (1) cattle remains predominate in faunal assemblages of Southern Neolithic sites; (2) numerous limb-bone specimens have been reported with pathologies consistent with use for traction labor (Alur 1971); and (3) aged specimens suggest females were used for dairying (P. Thomas 1989). Although Neolithic sites containing ashmounds have been described as being distinctive from habitation sites without ashmounds (Fuller 2001; Korrisettar et al. 2001b), the faunal contents of these assemblages do not differ significantly. For example, the remains of domesticated animals such as sheep/goat, dog, and cattle (both zebu and water buffalo), as well as wild animals, are present at sites both with and without ashmound features (Allchin 1961; Alur 1971; Clason 1975; Monahan in press; Nagaraja Rao 1965; Nath 1968; Rami Reddy 1976; P. Thomas 1984, 1989).

While wild taxa have been recovered at several Neolithic sites in the region (cf. Paddayya 1993), there is a low reported incidence of such fauna. This situation may be symptomatic of recovery methods that do not involve screening deposits, whereby materials from small mammals, reptiles, birds, or fish are likely not recovered from sites. Hence, the significance of wild taxa to the animal economies during the Neolithic and subsequent periods remains poorly understood. However, recent work by Miracle (2005) has provided some insight. He identified wild-resource exploitation in sporadically occupied Neolithic (and perhaps earlier) cave sites in the Kurnool District (Andhra Pradesh). Indeed, these assemblages are heavily dominated by wild taxa and stand in stark contrast to contemporaneous Neolithic habitation and ashmound sites; Miracle suggests that these cave sites evidence hunting/collecting of wild forest resources and observes 
above. Indeed, diversified crop production and the development of water management must be considered within the broader context of increasing social differentiation that became marked by the Iron Age and Early Historic periods. For example, an increase in rice production and shifts from a reliance on runoff agriculture to reservoir irrigation and floodwater farming would produce a new material order on the landscape that was necessarily connected to sociopolitical fields and potentially relates to changing social relations of production. Indeed, the relative positions of certain reservoir features - in the middle of settlements, at the base of outcrops, and in secluded ritual locales-may already suggest differences in sociopolitically prescribed accessibility to water as a material and symbolic resource. With regard to agriculture, the questions (a) Who crops where? (b) Who crops what? and (c) How is this decided? take on added significance as the social and material conditions for producing culturally valued items changed. If, for example, irrigated rice became a more culturally valued cultigen than dry-farmed millets, then the negotiation of access to floodplain land or limited amounts of reservoir water could have reinforced or reconfigured developing sociopolitical differences. In fact, the placement of certain megalithic monuments relative to water might have expressed such claims (see monumental section above). Furthermore, the organization of labor for constructing a reservoir and practicing both irrigation and dry agriculture was also an important component of this process. For instance, the degree and temporality of group labor required for increasingly intensive irrigation agriculture versus rain-fed crops might have reinforced or reconfigured social categories of kin, community, or sociopolitical positionality. In short, changing agricultural regimes and associated landscape features likely included a new and diverse set of material and symbolic resources on which social power was based.

\section{DISCUSSION}

The consideration of animal use, agricultural regimes, and monumentality reveals intersections among these modes of land use that greatly inform the examination of sociopolitical differentiation in the southern Deccan between 3000 B.C. and A.D. 500. Moreover, both changes and continuities in cultural logics and knowledge systems are more clearly evidenced by considering the empirical components of these three processes in tandem. Indeed, the historiographic categories of the Neolithic (3000-1200 B.c.), Iron Age (1200-500 B.c.), and Early Historic (500 B.C.-A.D. 500) periods in southern India do not represent discrete sociocultural phenomena (e.g., "cultures") that can be rigidly characterized according to a normative framework; the history of land use and human-environment interaction throughout these periods is not marked by dramatic discontinuities and "catastrophic" changes. Although clearly, some aspect of land use-such as the development of irrigated rice agriculture - might have markedly affected existing social relations of production, there is also a variety of more subtle differences in land and animal use that emerged in concert with the historical production of sociopolitical differences and ecological-material contexts (see also Fig. 2).

Indeed, there appear to be continuities between patterns of animal use and agricultural regimes in the third and early second millennia B.C. and those of the late second and first millennia B.C. Faunal data suggest slight shifts in animal use strategies between periods, as the importance of both wild faunal and cattle remain in 
evidence at Neolithic, Iron Age, and Early Historic Period sites. Moreover, botanical finds from southern Deccan sites suggest that certain varieties of millets, cultivated in the Neolithic, remained important cultigens throughout the following millennia. In this sense, there is a clear resilience to certain modes of humanenvironment interaction rooted in the confluence of ecological conditions and knowledge systems. Nevertheless, there are also definitive differences in agropastoral practices between the periods considered. At a general level, late second and first millennia B.C. deposits suggest that wider varieties of cultivar resources were incorporated into the lifeways of southern Deccan inhabitants, as attested by the introduction of several new cultigens at sites throughout the region. Moreover, faunal data from Kadebakele indicate a potential increased emphasis on hunted, nonmammalian wild taxa during the Iron Age. This pattern of diverse animal use is not likely unique to Kadebakele, but rather it evinces the strong bias against the recovery of nonmammalian species by archaeological method of unscreened hand collection widely employed throughout the region. However, the screening of archaeological deposits cannot be considered wholly responsible for the predominance of small, wild taxa at Kadebakele when compared to some sites. In fact, the screened faunal assemblage from Neolithic deposits at VMS 110, a site near Kadebakele, yielded a species spectrum quite similar to other Neolithic sites in the region (Monahan in press), suggesting that the dominance of cattle in these earlier contexts is not solely a function of sampling strategies. Nevertheless, it is important to note that our interpretations are subject to revision, as the abundance of nonmammalian taxa in South Indian archaeological assemblages is currently unclear because these animals have often been recorded as simply present or absent, while mammalian specimens are recorded and reported as NISP values.

The diversification of agricultural production and the use of both wild and domesticated animals in Iron Age and early historic lifeways likely accompanied changing logics, understandings, and cultural valuations that can be linked to emerging social differences. This may be particularly true of agricultural production and irrigated agriculture in particular, where two potentially sacralized elements - water and dung-were brought together in the landscape. Indeed, accepting that the cultural associations of water and dung were applicable to agricultural production, the historical developments of water management and crop diversity during the first millennium B.C. may have involved a process whereby certain cultigens were culturally attributed with new meanings. For example, despite the continued production of millets throughout the period, the crops' cultural status may have changed as irrigated rice became differentially available, and different cultigens were perhaps even incorporated into ritual feasting events. Importantly, the ability to produce or consume unequally valued foods would have been mediated through sociopolitical relations that were reproduced and reconfigured through the processes of production and consumption. In other words, the relative involvement in the agricultural process and the consumption of its produce might have been one axis on which social power became expressed and based, allowing for a material dimension through which sociopolitics could be negotiated.

A similar argument can be made for animal use at Kadebakele, as both hunting and local stockbreeding practices appear to have been important components of social life during the first millennium B.C. The confluence of these different sets 
of strategies suggests that numerous axes of distinction were overlain and differentially highlighted according to the organization of labor and consumption practices. Indeed, the presence of both large domestic taxa often associated with communal feasting and smaller game animals characteristic of household consumption suggests that social distinctions were regularly produced through instrumental sociopolitical events and the differential consumption of certain foods. In fact, Sinopoli (2005b) has suggested that the widespread appearance of small "hemispherical or carinated bowls" during the Iron Age might also relate to new modes of public consumption activities, such as feasting. Thus, it is not surprising that these characteristics of the faunal data coincide with indications for new modes of power relations and labor mobilization, attested through the construction of both megaliths and reservoirs. In this sense, associations between sociopolitical differences and the materiality that they created and operated within also became embedded in the landscape.

The presence of new landscape features such as reservoirs and megaliths allowed places to emerge that potentially produced and altered perceptions of developing sociopolitical relationships. As the landscape came to include a matrix of places-where crops were differentially watered, animals were herded, game was hunted, monuments were erected, and rituals were performed-its production took on an instrumentality that allowed for the reproduction and contestation of social differences, as access to agro-pastoral products and symbolic resources such as water were materialized through daily activities, ritual performance, and monument production. In other words, the landscape itself can be considered a social product through which associations and differences were experienced and perceived. Hence it is possible to contrast Neolithic ashmoundsgenerally associated with community access and corporate practices- to Iron Age mortuary megaliths that tend to highlight elite individuals or possibly kin groups in restricted settings. In this sense, we suggest that the historical development of the landscape is both the artifact and medium of sociopolitics in early South India. Moreover, the contemporary ecological conditions of the southern Deccan continue to reflect the long-term history of these sociopolitics; for example, less xerophytic vegetation currently grows in moisture-retaining, clay-rich sediments that have accumulated in Iron Age and Early Historic Period reservoirs. In fact, the persistent vegetation in these depressions, in an otherwise semi-arid region, often makes the features identifiable with infrared multispectral satellite imagery (e.g., Aster and Landsat ETM+). In this case, the relationship between environment and "culture change" should be briefly readdressed.

The connections between environmental phenomena and sociocultural history remain fruitful avenues of inquiry in South India. However, arguments that the environment provided a stimulus for "cultural change" in the past often overlook interesting sociopolitical and cultural dimensions of history, and they tend to overstate the determinacy of an abstracted, peopleless "environment." To accept that material environments are products of sociopolitical strategies as much as they are hydrological, geomorphological, vegetational, and zoological processes is to redirect analysis onto how ecological-material phenomena are configured in sociocultural contexts. If, for example, the introduction of early water management techniques, new cultigens, and diversified hunting accompanied a weakening monsoon in the mid-second millennium B.C., efforts at understanding existing 
social relations and cultural logics involved in these diversified activities must be part of the analysis. For example, how did existing cultural conceptions and social strategies influence land use as wild taxa were differentially included in the diet and domestic animal traction became more important for agriculture? What new meanings were attributed to materials and places as previously sacralized items (e.g., dung and water) found new uses in the landscape and social access was renegotiated? In other words, the historical connections between cultural conceptions and the configuration of existing sociopolitical relationships through processes and strategies of producing and mobilizing sociosymbolic resources are central to an examination of how environmental and social histories are joined. The analyses of faunal data from Kadebakele indicate differential consumption and production of wild and domestic animals, as well as possibly unequal participation in feasting events, suggesting that there was likely differential access to at least one dimension of the social resources upon which power was based. Moreover, preliminary associations between megalithic monuments and culturally significant water pools are suggestive of unequal claims of access to "ritual" water. In this sense, the determinants of social history remain in social and cultural fields of action, though not removed from the ecological-material world of which people are a part. In sum, it is the historical development of such relationships to which we call attention in tracing land use from the Neolithic period through the Early Historic Period in an effort to investigate how social relationships are both a producer and a product of landscape histories.

\section{CONCLUSION}

While the above sketch is based on preliminary research and review, it suggests how the concerns of political ecology and landscape history can be considered instrumental in the development of social differentiation in early South India. By integrating concerns for cultural logics and sociopolitical relations of power with the materiality of landscape production and ecological phenomena in general, we argue that political ecology provides a useful framework for conceptualizing the history of early South India. Indeed, the similarities and differences among the historiographic categories of the Neolithic (3000-1200 B.C.), Iron Age (1200-500 B.C.), and early historic (500 B.C.-A.D. 500) periods cannot easily be explained solely by episodes of migration and diffusion of "culture groups" or "catastrophic" changes due to environmental stimuli. Rather, the social and cultural history of these periods must be considered as a series of sociohistorical processes that relate to ecological-material phenomena as both producers and products. Hence, the determinants of social history remain in social and cultural fields of action, though not removed from the ecological-material world of which people are a part.

The above sketch remains speculative and begs many additional research questions. Future analysis should be directed toward exploring the relationships between social transformations documented throughout the Iron Age and Early Historic Period and more detailed changes in both consumption and production strategies. Indeed, there have been no detailed investigations of differential consumption of irrigated (e.g., rice) and dry-farmed (e.g., millets) cultigens during these early periods, although the distinction becomes quite significant socially in 
later periods when rice was the preferred donation to Hindu temple deities (Morrison in press a). It will be important to further investigate how local patterns of land use are differentiated spatially and temporally through excavation, survey, and specialized botanical, faunal, and geoarchaeological analyses. Keeping in mind the documented material continuity between the Iron Age and Early Historic Period, it will be interesting to observe shifts in land and animal use with the expanding social networks and specialized production generally attributed to the Early Historic Period.

\section{ACKNOWLEDGMENTS}

We would like to thank Drs. Kathleen Morrison, Carla Sinopoli, and R. Gopal, codirectors of the Early Historic Landscapes of the Tungabhadra Corridor (EHLTC) research project for their ever-present help and guidance. The research presented here would not have been possible without their support and our invited participation in the EHLTC project. We are grateful to the Directorate of Archaeology and Museums of the Government of Karnataka, department directors Mr. Ram Krishna and Dr. R. Gopal, and deputy director T. S. Gangadhar for their support. We would also like to extend our thanks to the American Institute of Indian Studies, their director emeritus Dr. Pradeep Mehendiratta, director Purnima Mehta, and Elise Auerbach for their assistance and sponsorship and to the Government of India and the Archaeological Survey of India for granting EHLTC permission to conduct this research. Special thanks to Susan Scott, P. K. Thomas, and Arati Deshpande for insight and assistance with the faunal analysis component of this research. The authors would like to express gratitude to the following agencies for providing funding for the EHLTC project: the University of Chicago, University of Pennsylvania, American Institute for Indian Studies, National Geographic Society, National Science Foundation, and Wenner-Gren Foundation for Anthropological Research. In addition, we extend thanks to the people of Kadebakele village for their hospitality and support. Lastly, we would like thank three anonymous reviewers for their constructive insights regarding the content of this article. Any responsibility for errors or opinions remains with the authors alone.

\section{NOTES}

1. To be clear, in this paper we do not take significant issue with the empirics of the material chronology of South Indian prehistory, nor the scheme of periodization. Indeed, both are useful (and necessary) for discussing chronological issues and apparent changes in South Indian pre/ protohistory, and as such we use the nomenclature of these periods throughout the article. We do, however, problematize the "culture-history" paradigm that allows the use of the empirical/ material record to theoretically substantiate three packaged "cultures" associated with each period. This approach obfuscates analyses of social and political relationships by normalizing social, political, and economic behavior as a proxy for a culture type.

2. The "New Ecology" originally referred to Ecology's emerging interests in physico-chemical processes and trophic exchange around the middle of the $20^{\text {th }}$ century (Worster 1994). More recently, the term has been used to refer to developing theoretical emphases on chaos and disequilibrium, which is rooted in the 1970s (Scoones 1999).

3. Most of the material culture engaged in the construction of these archaeological cultures have temporal distributions that are exceedingly long, many of which begin in previous periods and/ or continue into later time, albeit in diminished proportions.

4. Hallur and Veerapuram are notable exceptions.

5. The construction of megalithic structures certainly extends into the Early Historic Period throughout much of South India. A recently analyzed carbon sample from megalith 6 excavated in the 1940 s by Wheeler suggests that the construction of megaliths may have begun as early as what is considered to be the middle of the Neolithic period (Morrison 2005; see also Devaraj et al. 1995). 
6. See Korisettar et al. 2001b for a different perspective.

7. However, this does not mean that social differences on less archaeologically visible axes, such as gender or age, were not present (see Boivin 2004b).

8. However, cattle dung is incorporated into the construction of some megaliths, and in at least one documented case ashmound construction appears to continue well into the Iron Age (e.g., at Palavoy; Rami Reddy 1976).

9. In geomorphological terms, these "natural" pools are known variously as gnammas, rock pools, or weathering pits and are considered to be characteristic features of residual hills and inselbergs throughout the heavily weathered terrain of the tropics and subtropics (Porembski and Barthlott 2000; M. Thomas 1994).

10. The faunal data recovered and analyzed from Kadebakele are presented in greater detail in $R$. Bauer (2006).

11. It is important to briefly note that our consideration of ritual dimensions of animal use at Kadebakele is not predicated on what is often conceptualized as a dichotomous relationship between symbolic and economic realms of behavior (e.g., Grant 1989); instead, we recognize that ritual practices are not by nature precluded from occurring in "profane" contexts (i.e., middens [Moore 1986] or domestic structures [Beavitt 1989]).

12. See Clason 1975, Monahan in press, Nath 1968, and P. Thomas 1984.

13. This site is technically situated in a basin of sedimentary rocks east of the geological contacts discussed above in reference to the study region ( $\mathrm{Rao}$ 2002). However, it remains relevant due to considerations of its relative proximity and well-studied assemblages.

14. However, it is important to note that Devaraj et al. do not attribute any water-retaining "function" to this feature.

\section{REFERENCES}

Allchin, R.

1954 The Development of Early Culture in the Raichur District of Hyderabad. Ph.D. diss. University of London.

1961 Utnur Excavations. Andhra Pradesh Government Archaeological Series No. 5. Hyderabad: Government of India.

1963 Neolithic Cattle-Keepers of South India. Cambridge: Cambridge University Press.

Allchin, B., AND R. Allchin

1982 Rise of Civilization in India and Pakistan. Cambridge: Cambridge University Press.

ALUR, K. R.

1971 Faunal remains, in Protohistoric Cultures of the Tungabhadra Valley: A Report on Hallur Excavations: $120-130$, ed. M.S.N. Rao. Dharwar: M.S.N. Rao.

Bauer, A. M., And K. D. Morrison

In press Reservoirs and water management in Southern India and Sri Lanka. To appear in Encyclopedia of the History of Science, Technology, and Medicine in Non-Western Cultures, ed. H. Selin. New York: Springer.

BAUER, R. L.

2006 Animals in Social Life: Hunting and Herding in Iron Age Southern India. Ph.D. diss. University of Pennsylvania, Philadelphia.

Bauer, R. L., A. M. Bauer, and P. G. Johansen

2004 Socio-political contexts and land and animal-use in early South Asia: Review, preliminary findings, and prospects for research on the Southern Deccan, India. Paper presented at the conference of the American Anthropological Association, Atlanta.

BeAvitT, $\mathrm{P}$

1989 The ethnoarchaeology of sacrifice: Some comments on the visible and invisible with respect to human contact with the spirit world in Borneo. Anthropozoologica numéro spécial, Animal et Pratiques Religieuses: Les Manifestations Matérielles 173-180.

Begley, V.

1996 The Ancient Port of Arikamedu: New Excavations and Research 1989-1992, vol. 1. Pondichery: École Française D’Extrême-Orient.

Begley, V., and R. D. De Puma, eds.

1991 Rome and India: The Ancient Sea Trade. Madison: University of Wisconsin Press. 
BiersacK, A.

1999 Introduction: From the "New Ecology" to the new ecologies. American Anthropologist 101(1): 5-18.

Blaikie, P., and H. Brookfield

1987 Land Degradation and Society. London: Metheun.

Boivin, N.

2004a Landscape and cosmology in the South Indian Neolithic: New perspectives on the Deccan ashmounds. Cambridge Archaeological Journal 14 :235-257.

2004b Rock art and rock music: Petroglyphs of the South Indian Neolithic. Antiquity 78:3853.

Botkin, D. B.

1990 Discordant Harmonies: A New Ecology for the Twenty-First Century. New York: Oxford University Press.

BRADley, R.

1998 The Significance of the Monuments: On the Shaping of Human Experience in Neolithic and Bronze Age Europe. London: Routledge.

2000 Archaeology of Natural Places. London: Routledge.

BRUBAKER, R.

2001 Aspects of mortuary variability in the South Indian Iron Age. Bulletin of the Deccan College Post-Graduate and Research Institute 60-61:253-302.

Butzer, K. W.

1982 Archaeology as Human Ecology. Cambridge: Cambridge University Press.

Caratini, C., I. Bentaleb, M. Fontugne, M. T. Morzadec-Kerfourn, J. P. Pascal, and C.

TISSOT

1994 A less humid climate since ca. 3500 yr B.P. from marine cores off Karwar, western India. Palaeogeography Palaeoclimatology Palaeoecology 109(224): 371-384.

Cimino, R. M.

1994 Ancient Rome and India: Commercial and Cultural Contacts between the Roman World and India. New Delhi: Munshiram Manoharlal.

Clason, A. T.

1975 Archaeozoological study in India: Aspects of stock-breeding and hunting in prehistoric and early historic times. Eastern Anthropologist 28(1):1-12.

Cosivi, O., J. M. Grange, C. J. Daborn, M. C. Raviglione, T. Fujikura, D. Cousins, R. A.

Robinson, H.F.A.K. Huchzermeyer, I. D. Kantor, and F.-X. Meslin

1998 Zoonotic tuberculosis due to Mycobacterium bovis in developing countries. Emerging Infectious Diseases 4(1):59-70.

Crumley, C. L.

1994 Historical ecology: A multidimensional ecological orientation, in Historical Ecology: Cultural Knowledge and Changing Landscapes: 1-16, ed. C. L. Crumley. Santa Fe: School of American Research.

Cullen, H. M., P. B. De Menocal, S. Hemming, G. Hemming, F. H. Brown, T. Guilderson, AND F. SIROCKO

2000 Climate change and the collapse of the Akkadian empire: Evidence from the deep sea. Geology 28:379-382.

DAHL, G., AND A. HJORT

1976 Having Herds: Pastoral Growth and Household Economy. Stockholm Studies in Social Anthropology. Stockholm: University of Stockholm.

Descola, P.

1994 In the Society of Nature: A Native Ecology in Amazonia. Cambridge: Cambridge University Press.

Devaraj, D. V., J. G. Shaffer, C. S. Patil, and Balasubramanya

1995 The Watgal excavations: An interim report. Man and Enivronment 20(2):57-74.

DhaVAlikar, M. K.

1984 Toward an ecological model for chalcolithic cultures of central and western India. Journal of Anthropological Archaeology 3:133-158. 
Dietler, M., AND B. HAyden, eds.

2001 Feasts: Archaeological and Ethnographic Perspectives on Food, Politics and Power. Washington, DC: Smithsonian Institute.

ERICKSON, C. L.

1999 Neo-environmental determinism and agrarian collapse in Andean prehistory. Antiquity $73: 634-642$.

ESCOBAR, A.

1999 After nature: Steps to an anti-essentialist political ecology. Current Anthropology 40(1): 131.

FAirhead, J., AND M. LEACH

1996 Misreading the African Landscape: Society and Ecology in a Forest-Savanna Mosaic. Cambridge: Cambridge University Press.

Foote, R. B.

1916 Prehistoric and Protohistoric Antiquities of India. Delhi: Leeladevi Publications.

Fuller, D. Q.

2001 Ashmounds and hilltop villages: The search for early agriculture in southern India. Archaeology International 4:43-46.

2003 Indus and non-Indus agricultural traditions: Local development and crop adoptions on the Indian Peninsula, in Indus Ethnobiology: New Perspectives from the Field: 343-396, ed. S. Weber and W. Belcher. Lanham, MD: Lexington Books.

Fuller, D. Q., AND R. Korisettar

2004 The vegetational context of early agriculture in South India. Man and Environment 29:727.

Fuller, D. Q., R. Korisettar, and P. C. Venkatasubbaiah

2001 Southern Neolithic cultivation systems: A reconstruction based on archaeobotanical evidence. South Asian Studies 17:171-187.

Gordon, D. H., AND F. R. Allchin

1955 Rock painting and engravings in Raichur, Hyderabad. Man 55: 97-99.

Greenberg, J. B., And T. K. Park

1994 Political ecology. Journal of Political Ecology 1:1-12.

Gururaja Rao, B. K.

1972 Megalithic Culture in South India. Prasanga: University of Mysore.

HaRvey, D.

1990 The Condition of Postmodernity. Cambridge, MA: Blackwell.

India Meteorological Department

1981 Climatological Atlas of India: Part A (Rain Fall). New Delhi: Government of India.

INGOLD, $T$.

2000 The Perception of the Environment. London: Routledge.

Jackson, H. E., and S. L. ScotT

1995 The faunal record of the southeastern elite: The implications of economy, social relations, and ideology. Southeastern Archaeology 14(2): 103-119.

2003 Patterns of elite faunal utilization at Moundville, Alabama. American Antiquity 68(3):552572.

Johansen, P. G.

2003 Recasting the foundations: New approaches to regional understandings of South Asian archaeology and the problem of culture history. Asian Perspectives 42(2): 193-206.

2004 Landscape, monumental architecture, and ritual: A reconsideration of the South Indian ashmounds. Journal of Anthropological Archaeology 23 :309-330.

Jones, N. B., ANd M. J. Konner

1976 !Kung knowledge of animal behavior (or: The proper study of mankind is animals), in Kalahari Hunter-Gatherers: Studies of the !Kung San and Their Neighbors: 326-348, ed. R. B. Lee and I. DeVore. Cambridge, MA: Harvard University Press.

KAJALE, M. D.

1984 Appendix: Botanical remains from Veerapuram, in Veerapuram: A Type Site for Cultural Study in the Krishna Valley: i-xi, ed. T.V.G. Sastri, M. Kasturi Bai, and J.V.P. Rao. Hyderabad: Archaeological and Cultural Research Institute. 
1989 Ancient grains from excavations at Hallur (1976 season), District Dharwar, Karnataka. Bulletin of the Deccan College Research Institute 47-48:123-128.

KHAN, A. W.

1963 A Monograph on Yeleswaram Excavations. Hyderabad: Government of Andhra Pradesh.

KiJngam, A.

1979 The Faunal Spectrum of Ban Chiang and Its Implications for Thai Culture History. Unpublished M.A. thesis. University of Otago, New Zealand.

Kolata, A. L., M. W. Binford, M. Brenner, J. W. Janusek, and C. Ortloff

2000 Environmental thresholds and the empirical reality of state collapse: A response to Erickson (1999). Antiquity $74: 424-426$.

Korisettar, R., P. P. Joglekàr, D. Q. Fuller, and P. C. Venkatasubbaiah

2001a Archaeological re-investigation and archaeozoology of seven Southern Neolithic sites in Karnataka and Andhra Pradesh. Man and Environment 26(2): 47-66.

Korisettar, R., and S. N. Rajaguru

2002 Understanding man-land relationships in peninsular Deccan: With special reference to Karnataka, in Indian Archaeology in Retrospect, vol. 4: Archaeology and Historiography: History, Theory and Method: 243-296, ed. S. Settar and R. Korisettar. New Delhi: Manohar.

Korisettar, R., P. C. Venkatasubbaiah, and D. Q. Fuller

2001b Brahmagiri and beyond: The archaeology of the Southern Neolithic, in Indian Archaeology in Retrospect, vol. 1: Prehistory Archaeology of South Asia: 151-237, ed. S. Settar and R. Koristtar. New Delhi: Manohar.

Krishna Sastry, V. V.

2003 Megalithic cultures: The Iron Age, in Pre and Protohistoric Andhra Pradesh Up to 500 BC: 107-138, ed. M.L.K. Murthy. Chennai, India: Orient Longman.

Krishnaswami, V. D.

1949 Megalithic types of South India. Ancient India 5:35-45.

Kus, S. M., AND V. RahariJaOna

2000 House to palace, village to state: Scaling up architecture and ideology. American Anthropologist 102(1): 98-113.

LATOUR, B.

2004 The Politics of Nature: How to Bring the Sciences into Democracy. Cambridge, MA: Harvard University Press.

LEE, R. B.

1968 What hunters do for a living, or, how to make out on scarce resources, in Man the Hunter: 30-48, ed. R. B. Lee and I. Devore. Chicago: Aldine.

LEFEBVRE, $\mathrm{H}$.

1991 The Production of Space. Malden, MA: Blackwell.

Lepofsky, D., K. Lertzman, D. Hallett, and R. Mathewes

2005 Climate change and cultural change on the southern coast of British Columbia, 24001200 ca. B.P.: An hypothesis. American Antiquity 70(2):267-293.

LESHNIK, L. S.

1974 South Indian "Megalithic" Burials: The Pandukal Complex. Wiesbaden: Steiner.

Lycett, M. T., AND K. D. Morrison

1998 Scales and monumentalities: The production of an Iron Age landscape in north interior Karnataka. Paper presented at the Ninety-Seventh Annual Meeting of the American Anthropological Association, December 1-3, Philadelphia, PA.

MARKS, S. A.

1979 Profile and process: Subsistence hunters in a Zambian community. Africa 49(1):53-67.

Meher-Homji, V. M.

1993 Climate changes over space and time: Their repercussions on the flora and vegetation. Palaeobotanist 43:225-240.

1996 Monsoon: A bioclimatologist's point of view. Current Science 71:352-357.

Miracle, P.

2005 The stability of hunting and gathering in the prehistory of South India. Paper presented at the meetings of the European Association of South Asian Archaeologists, London, July. 
Monahan, B. H.

In press South Indian animal use: Subsistence practices and exchange patterns, in Recent Research on the Archaeology and Paleoanthropology of South India, ed. V. V. Rami Reddy and K. D. Morrison. New Delhi: Munshiram Manoharlal.

Moore, H.

1986 Space, Text and Gender: An Anthropological Study of the Marakwet of Kenya. Cambridge: Cambridge University Press.

MOORTI, U.

1994 Megalithic Culture of South India: Socio-Evolutionary Perspectives. Varanasi: Ganga Kaveri Publishing House.

\section{MORrison, K. D.}

1994 States of theory and states of Asia: Regional perspectives on states in Asia. Asian Perspectives 22(2): 183-196.

1995a Trade, urbanism and agricultural expansion: Buddhist monastic institutions and the state in the early historic western Deccan. World Archaeology 27(2):203-221.

1995b Fields of Victory: Vijayanagara and the Course of Intensification. Contributions of the University of California Archaeological Research Facility 53. Berkeley: University of California.

2004 On putting time in its place: Landscape history in South India. Paper presented at the University of Pennsylvania Ethnohistory Seminar, November 11, Philadelphia, PA.

2005 Brahmagiri Revisited: A Re-Analysis of the South Indian Sequence, in South Asian Archaeology, 2001: 1-10 ed. C. Jarrige and V. LeFevre, Editions Recherche sur les Civilisations. Paris: ADPF.

In Oceans of Dharma. Seattle: University of Washington, and Delhi: Permanent Black.

press a

In The Daroji Valley: Landscape History, Place, and the Making of a Dryland Reservoir System. press b Delhi: Manohar Press.

Morrison, K. D., C. M. Sinopoli, B. Gopal, A. M. Bauer, R. L. Bauer, E. Bridges, and P. G. JOHANSEN

n.d. Late Prehistoric and Early Historic Landscapes of the Tungabhadra Corridor: Report of the 2005 Season. Report submitted to the Archaeological Survey of India, Delhi.

Mujumdar, G. G., and S. N. Rajaguru

1966 Ashmound Excavations at Kupgal. Poona: Deccan College Post-Graduate and Research Institute.

MurTy, M.L.K.

1992 Hunter-gatherers, pastoralists and the state in southwestern Andhra Pradesh, South India, in Ethnoarchéologie: Justification, Problèmes, Limites: 325-338, ed. F. Audouze. Rencontres Internationales D'Archéologie et D'Histoire D'Antibes 12. Juan-les-Pins: APDCA.

Nagaraja Rao, M. S.

1965 The Stone Age Hill Dwellers of Tekkalakota. Poona: Deccan College.

NAQVi, S. M., AND J.J.W. ROGERS

1987 Precambrian Geology of India. Oxford Monographs on Geology and Geophysics 6. New York: Clarendon Press.

NATH, B.

1968 Advances in the study of prehistoric and ancient animal remains in India: A review. Records of the Zoological Survey of India 61(1-2): 1-290.

Neumann, R. P.

2004 Nature-state-territory: Toward a critical theorization of conservation enclosures, in Liberation Ecologies: Environment, Development, and Social Movements, 2nd ed.: 195-217, ed. R. Peet and M. Watts. London: Routledge.

PADDAYYA, K.

1991 The ashmounds of South India: Fresh evidence and possible implications. Bulletin of the Deccan College Post-Graduate Research Institute 51-52:573-626.

1993 Ashmound investigations at Budhihal, Gulbarga District, Karnataka. Man and Environment 18(1):57-87.

1998 Evidence of Neolithic cattle-penning at Budihal, Gulbarga District, Karnataka. South Asian Studies 14:141-153.

2001 The problem of ashmounds of southern Deccan in the light of Budihal excavations, Karnataka. Bulletin of the Deccan College Post-Graduate Institute (Diamond Jubilee Volume) 6061:189-225. 
Paddayya, K., P. K. Thomas, and P. P. Joglekar

1995 A Neolithic animal butchering floor from Budihal, Gulbarga District, Karnataka. Man and Environment 20(2):23-31.

Paulson, S., L. L. Gezon, and M. Watts

2005 Politics, ecologies, and genealogies, in Political Ecology across Spaces, Scales, and Social Groups: 17-37, ed. S. Paulson and L. L. Gezon. New Brunswick, NJ: Rutgers University Press.

Peet, R., And M. Watts

1996 Liberation ecology: Development, sustainability, and environment in an age of market triumphalism, in Liberation Ecologies: Environment, Development, and Social Movements: 145 , ed. R. Peet and M. Watts. London: Routledge.

Phadtare, N. R.

2000 Sharp decrease in summer monsoon strength $4000-3500$ cal yr B.P. in the central higher Himalya of India based on pollen evidence from alpine peat. Quaternary Research 53:122129.

Porembski, S., AND W. Barthlott, eds.

2000 Inselbergs: Biotic Diversity of Isolated Rock Outcrops in Tropical and Temperate Regions: New York: Springer.

Potter, J. M., and S. G. Ortman

2004 Community and cuisine in the prehispanic American Southwest, in Identity, Feasting and the Archaeology of the Greater Southwest: 173-191, ed. B. J. Mills. Boulder: University of Colorado Press.

RAMI REDDY, V.

1976 The Prehistoric and Protohistoric Cultures of Palavoy, South India (with Special Reference to the Ashmound Problem). Hyderabad: Government of Andhra Pradesh.

RAO, J. V.

2002 Prehistoric Environment and Archaeology of the Krishna-Tungabhadra Doab. Delhi: C. P. Gautam.

RAPPAPORT, R. A.

1968 Pigs for the Ancestors: Ritual Ecology of a New Guinea People. New Haven: Yale University Press.

RAY, H. P.

1986 Monastery and Guild: Commerce under the Satavahanas. Delhi: Oxford University Press.

2003 The Archaeology of Seafaring in Ancient South Asia. Cambridge: Cambridge University Press.

REA, A.

1903 Adichanallur excavations. Annual Report of the Archaeological Survey of Madras and Coorg for the Year 1902-1903: 9-14.

Rocheleau, D.

1999 Commentary on "After nature: Steps to an anti-essentialist political-ecology" by Arturo

Escobar. Current Anthropology $40: 22-23$.

SCOONES, I.

1999 New ecology and the social sciences: What prospects for a fruitful engagement? Annual Review of Anthropology 28: 479-507.

SHINDE, V.

1998 Early Settlements in the Tapti Basin. Delhi: Munshiram Manoharlal.

SINGH, N. P.

1988 Flora of Eastern Karnataka. Delhi: Mittal.

SinOPOLI, C. M.

2001 On the edge of empire: Form and substance in the Satavahana Dynasty, in Empires: Perspectives from Archaeology and History: 155-178, ed. S. Alcock, T. D’Altroy, K. Morrison, and C. Sinopoli. Cambridge: Cambridge University Press.

2005a Late prehistoric and early historic landscapes of the Tungabhadra corridor. Paper presented at the conference for the European Association of South Asian Archaeologists, July 4-8, London.

2005b Far horizons: Scale, society, and political complexity in first millennium BCE South India. Paper presented at Complex Societies Conference, September, Flagstaff, AZ. 
Sinopoli, C. M., P. G. Johansen, and K. D. Morrison

In press Changing cultural landscapes of the Tungabhadra Valley, South India, in States and the Landscape, ed. S. Falconer and C. L. Redman. Tucson: University of Arizona Press.

Sinopoli, C. M., AND K. D. Morrison

2003 Early historic landscapes of the Tungabhadra corridor. Paper presented at the Second Annual Conference on South Asia, October 24-26, Madison, WI.

Sмiтн, A. T.

1999 The making of an Urartian landscape in Southern Transcaucasia: A study of political architectonics. American Journal of Archaeology 103(1): 45-72.

2003 The Political Landscape: Constellations of Authority in Early Complex Societies. Berkeley: University of California Press.

Smith, A. T., AND N. DAvid

1995 The production of space and the House of Xidi Sukur. Current Anthropology 36(3):441470.

SPETH, J. D.

1983 Bison Kills and Bone Counts: Decision Making by Ancient Hunters. Prehistoric Archaeology and Ecology Series. Chicago: University of Chicago Press.

SPOONER, B. J.

1973 The cultural ecology of pastoral nomads. Current Topics in Anthropology 8(45):1-56.

Subash Chandran, M. D.

1997 On the ecological history of the Western Ghats. Current Science 73:146-155

SugANDHI, N. S.

2003 Context, content, and composition: Questions of intended meaning and the Asokan edicts. Asian Perspectives 42(2): 224-246.

Thaper, B. K.

1957 Maski 1954: A chalcolithic site of the southern Deccan. Ancient India 13:4-142.

THomas, M. F.

1994 Geomorphology in the Tropics: A Study of Weathering and Denudation in Low Latitudes. Chichester: John Wiley \& Sons.

THomas, P. K.

1984 Appendix-C: Faunal assemblage of Veerapuram, in Veerapuram: A Type Site for Cultural Study in the Krishna Valley: i-xi, ed. T.V.G. Sastri, M. Kasturi Bai, and J.V.P. Rao. Hyderabad: Archaeological and Cultural Research Institute.

1989 Utilization of domestic animals in pre- and protohistoric India, in The Walking Larder: Patterns of Domestication, Pastoralism and Predation: 108-112, ed. J. Clutton-Brock. London: Unwin Hyman.

1992 The faunal background of the Iron Age culture of Maharashtra. Man and Environment 17(2): 75-79.

1993 Faunal remains from the megalithic habitation site at Bhagimohari, Vidarbha, Maharashtra. Man and Environment 18(2):105-118.

Thomas, P. K., and P. P. Joglekar

1994 Holocene faunal studies in India. Man and Environment 19:179-203.

VAN DER LeEUW, S. E.

1998 Understanding the Natural and Anthropogenic Causes of Land Degradation and Desertification in the Mediterranean Basin: The Archaeomedes Project. Luxembourg: Office for Official Publications of the European Communities.

Vayda, A. P., ANd B. B. Walters

1999 Against political ecology. Human Ecology 27:167-179.

Weiss, H., M. A. Courty, W. Wetterstrom, F. Guichard, L. Senior, R. Meadow, and A. Curnow

1993 The genesis and collapse of third millennium North Mesopotamian civilization. Science $261: 995-1004$

WHEELER, R.E.M.

1948 Brahmagiri and Chandravalli 1947: Megalithic and other cultures in Mysore State. Ancient India 4:181-231. 
WOLF, E. R.

1972 Ownership and political ecology. Anthropological Quarterly 45:201-205.

WORSTER, D.

1994 Nature's Economy: A History of Ecological Ideas, 2nd ed. New York: Cambridge University Press.

\section{ABSTRACT}

The archaeology of southern India has long been dominated by cultural-historical paradigms, which have more recently become reliant on environmental stimuli to explain "culture change." This interpretive framework has created a relatively fixed set of relationships between the environment and past human societies that oversimplifies issues of agency and causation in largely deterministic terms. At issue here is a lack of adequate treatment for the sociopolitical complexity of human-environment relationships. In this essay we examine the relationships between emerging social differences and both stable and dynamic aspects of land use throughout the South Indian Neolithic (3000-1200 в.C.), Iron Age (1200-500 в.c.), and Early Historic (500 B.C. - A.D. 500) periods in the southern Deccan region of South India. In an effort to contextualize land use in wider sociopolitical realms, we focus on the empirical components of three aspects of the archaeological record-animal use, agricultural regimes, and monument production and maintenance-through a lens of political ecology. Accepting that land use is socially and culturally mediated, we suggest how sociopolitical distinctions emergent during these periods could be viewed in relation to the production of a landscape that differentially included wild and domesticated animals, cultivars, water reservoirs, irrigation agriculture, and monumental architecture. In this sense, we argue that the landscape itself could be seen as a social product through which sociopolitical differences were experienced and perceived, and that the historical development of the landscape is both the artifact and medium of sociopolitics in early South India. As such, the determinants of social history remain in social and cultural fields of action, though not removed from the ecological-material world of which people are a part. KEYwORDs: agriculture, landscapes, monumentality, political ecology, zooarchaeology. 